\title{
Ordningen af det højere skolevæsen i Sønderjylland 1918-1920
}

\author{
af KAJ SøRENSEN
}

Det var et væsentligt spørgsmål i forbindelse med Genforeningen i 1920, hvordan det danske uddannelsessystem skulle indføres i den genvundne landsdel. Ikke mindst ordningen af de sønderjyske gymnasieskoler stillede store krav til de nye magthavere: Hvor skulle gymnasierne placeres? Hvem skulle lede dem i den første vanskelige tid efter genforeningen? Og hvordan skulle man håndtere det tyske mindretals krav og ønsker? Organist Kaj Sørensen, Taastrup, beretter her om de mange vigtige beslutninger, som skulle træffes, inden de nyindsatte danske rektorer på de sønderjyske gymnasier i sensommeren 1920 kunne åbne dørene for landsdelens unge.

I vinteren 1917-18 var det tydeligt for enhver, at verdenskrigen nærmede sig sin afslutning. Man var overbevist om, at Tyskland snart måtte give op, og det styrkede for mange håbet om, at Danmark kunne få i hvert fald en del af de landområder tilbage, som man i 1864 havde tabt til Tyskland.

Ratifikationen af Versaillesfreden og dermed også genforeningen med det tabte land trak imidlertid ud, men det havde $\mathbf{i}$ hvert fald én fordel: Der blev god tid til at overveje forholdene omkring den danske stats overtagelse af de nye danske landområder.

I december 1918 nedsatte Statsministeriet Det Sønderjyske Udvalg, også kaldet Kriegerudvalget efter formanden, kabinetssekretær A. Krieger. Udvalget fik til opgave at besvare forespørgsler vedrørende Nordslesvig og skulle derudover bistå de udvalg, som Nordslesvigsk Vælgerforenings tilsynsråd kort forinden havde nedsat til at udarbejde planer for de administrative og lovgivningsmæssige forandringer $\mathrm{i}$ forbindelse med genforeningen med Danmark. Med oprettelsen af Det midlertidige Ministerium for sønderjyske Anliggender (i daglig tale: Det sønderjyske Ministerium) den 24. juni 1919 overgik udvalgets opgaver hertil. ${ }^{1}$ 


\section{Skoleudvalget}

Et af de udvalg, som Vælgerforeningens tilsynsråd nedsatte, var Det Nordslesvigske Skoleudvalg. Dets arbejde var, som arbejdet i de øvrige udvalg, af rent forberedende art, og opgaven var at bistå med indførelsen af den danske folkeskole $i$ landsdelen samt at udarbejde forslag til en lovgivning på området, især i forhold til det fremtidige tyske mindretal.

I centrum for den følgende beretning står den såkaldte højere skole i Sønderjylland, det vil sige de sønderjyske gymnasieskoler. Når skoleudvalget og dets arbejde omtales, skyldes det, at skoleudvalget også drøftede og rådgav ministeriet vedrørende ordningen af det højere skolevæsen i Sønderjylland, et forhold som ofte bliver forbigået i de forskellige beretninger om skoleudvalget og dets arbejde. I udkast af 10 . december 1919 til "Forslag til Lov om Oprettelse af Statsskoler i Sønderjylland “ pointeres det da også udtrykkeligt, at bestemmelsen om statsskolernes beliggenhed, antal og art er foreslået efter forhandling med det af den nordslesvigske Vælgerforening nedsatte skoleudvalg.

Skoleudvalget blev nedsat på Vælgerforeningens historiske møde den 11. november 1918, men trådte først sammen sidst $i$ januar 1919, idet man løb ind i problemer med udvalgets sammensætning.

Arbejdet i skoleudvalget blev ikke uproblematisk. Medlemmerne havde på nogle områder svært ved at blive enige om, hvilken linie der skulle lægges. Det gjaldt eksempelvis spørgsmålet om det tyske mindretals rettigheder. Alle var enige om, at det tyske mindretal skulle have lov til at oprette tyske skoler med tysk undervisningssprog, men man kunne ikke blive enige om, hvorvidt man skulle kræve dansk som obligatorisk fag i disse skoler. Derfor var man i et par tilfælde $\mathrm{i}$ indstillinger til ministeriet nødt til at ty til mindretals- og flertalsindstillinger, hvilket svækkede udvalget. Desuden fandt man samarbejdet med ministeriet belastende, idet man følte, at der tit var tale om påbud oppefra $i$ højere grad end egentlige forhandlinger. Da formanden Jefsen Christensen i begyndelsen af april 1919 havde været til møde i ministeriet, udtalte han om sin rolle i forhandlingerne, at den "må vel nærmest siges at være af afværgende natur over for statens egenmægtige optræden ... «² Arbejdet i skoleudvalget var tilmed meget tidskrævende, ikke mindst for formanden, som på trods af nogle timers daglig kontorhjælp måtte ansætte ekstra medhjælp til de daglige gøremål hjemme på gården. Man får i et brev fra april 
1920 et godt indtryk af formandens arbejdsbyrde: "Jeg sidder ved skrivebordet dagen igennem ... Skærtorsdag begyndte med 56 breve, påskelørdag fortsatte med 42, og så har det svinget mellem 30 og 50 breve daglig siden da ${ }^{3}{ }^{3}$

Ud over de syv medlemmer fik højskoleforstander Jacob Appel, Askov, sæde i udvalget. Det var formandens idé, og det skulle vise sig at blive af uvurderlig betydning, at netop Appel kom med. Han var født i Rødding, den tids kulturelle og nationale centrum i Sønderjylland, som søn af den sønderjyske præst og højskolemand Cornelius Appel. I 1906 blev Jacob Appel forstander for Askov Højskole, og selv om han aldrig direkte havde taget del i politik, blev han i 1910 udnævnt til kultusminister. Kultusministeriet omfattede dengang alle de sagsområder, der i dag dækkes af Undervisningsministeriet, Kulturministeriet og Kirkeministeriet, og Appel forblev på posten til 1913, hvor ministeriet Berntsen gik af. I skoleudvalget blev det Jacob Appels opgave skriftligt at udforme de retningslinier for en ny skolelov, som skoleudvalget kunne enes om, og stille det hele op i paragraffer, så det kunne indsendes som et forslag til den danske regering. Jacob Appel kom således $\mathrm{i}$ skoleudvalget til aktivt at tage del $\mathrm{i}$ forberedelserne af den nye sønderjyske skole, både hvad angik folkeskolen og det højere skolevæsen, og da han 1920-24 blev undervisningsminister i ministeriet Neergaard, blev det også ham, der kom til at føre lovens tanker og intentioner ud i livet. ${ }^{4}$

\section{Skoleudvalgets første møde}

Skoleudvalget afholdt sit første møde på Folkehjem i Aabenraa den 28. januar 1919. På dette møde diskuterede man så godt som udelukkende retningslinierne for det højere skolevæsen samt placeringen af real- og gymnasieskolerne i de landområder, som man forventede ville blive tilbageleveret til Danmark. Der var bred enighed om, at det fra første færd gialdt om at skabe så stærk en sammensmeltning af »sønderjysk « og »kongerigsk « som overhovedet muligt, et synspunkt, som både Undervisningsministeriet og senere også Det sønderjyske Ministerium fuldt ud delte.

Udvalget fandt det derfor vigtigt, at alle skoler inden for det højere skolevæsen blev oprettet som statsskoler, også realskolerne, selv om der ikke på det tidspunkt fandtes danske statsrealskoler. Staten havde nemlig, både med hensyn til det daglige tilsyn og med hensyn til lærer- 
udnævnelser, en langt større indflydelse på statsskolerne end på de kommunale og private skoler. Man diskuterede, om det ville være en fordel at oprette en tysk statsskole i Sønderjylland, eller om det var at foretrække i stedet at lave parallelklasser i de danske statsskoler. Man var imidlertid nervøs for, at parallelklasser i de danske statsskoler kunne give anledning til rivninger mellem kammeraterne, og udvalget foretrak derfor oprettelse af en tysk statsskole. Det blev besluttet at indstille til ministeriet, at det eventuelt kunne overlades til tyskerne selv at bestemme hvor i Sonderjylland, den tyske skole skulle placeres.

Udvalget udarbejdede på mødet følgende liste over de højere skolers fordeling og placering:

En dansk kostskole i Augustenborg

En højere tysk skole i Sønderborg

En dansk realskole i Sønderborg

En dansk realskole i Tonder

Et dansk gymnasium i Aabenraa

En dansk realskole i Haderslev

Et dansk gymnasium i Haderslev ${ }^{5}$

\section{Kostskoleplaner}

Der havde i et stykke tid, ikke mindst fra jysk side, været et ønske om at få en statskostskole i Jylland. Staten havde kort tid forinden rundhåndet støttet udvidelsen af Sorø Akademis Skole og derudover overtaget såvel Birkerød Kostskole som Rungsted Kostskole, så der nu på Sjælland var hele fire store kostskoler, statens tre og Herlufsholm. Det opfattede mange som en principiel anerkendelse af kostskolen som skoleform, og kravet om en jysk statskostskole voksede. Med Sonderjyllands indlemmelse mente mange, at nu var tiden kommet til at lægge pres på de bevilgende myndigheder i København og få den ønskede kostskole til denne egn af landet. ${ }^{6}$

Ønsket om en statskostskole i Sønderjylland kom altså ikke fra skoleudvalget, men udvalget støttede varmt tanken. Når man foreslog skolen placeret i Augustenborg, var det blandt andet, fordi der på Augustenborg Slot var velegnede lokaler til rådighed. Det kan dog ikke udelukkes, at nationale motiver også spillede ind her. Augustenborg havde nemlig tidligere været en tysk højborg, og at anbringe en dansk kulturinstitution netop her, ville udadtil være en tydelig manifestation af landsdelens nye tilhørsforhold. 


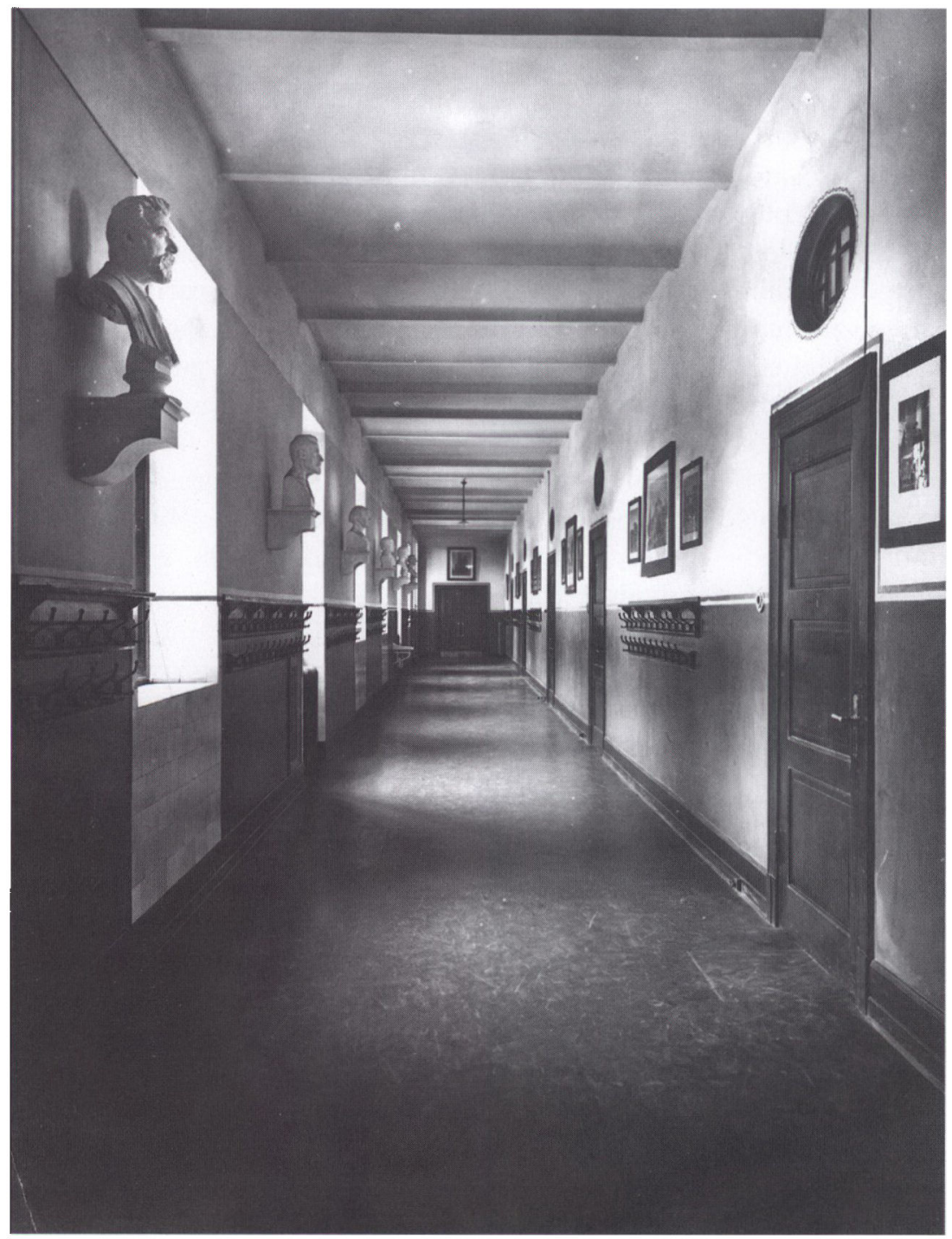

Fra en af gangene pd Sonderborg Statsskoles bygning på Kongevej. 1920'erne. Fra 1911 husede bygningen en realskole. I afstemningstiden var der usikkerhed om, hvorvidt skolen $i$ Sønderborg ville blive udvidet med et gymnasium. I begyndelsen af marts blev det bekendtgjort, at rektor Hertz fra Schneekloths Skole i Kobenhavn var udnæot til rektor $i$ Sønderborg. Dermed var sagen afgjort. Dagbladet Kabenhavn tog imidlertid et forbehold: Hvis Flensborg kom til Danmark, ville Hertz - som var fodt $i$ Flensborg - formentlig blive udnxont til rektor for den nye statsskole $i$ sin gamle fødeby. Foto: Museet på Sonderborg Slot. 
Augustenborg Slot havde i de første år efter afståelsen til Tyskland i 1864 været benyttet som lazaret og kaserne, men fra 1878 havde slottet fungeret som tysk kvindeseminarium. Med den danske stats overtagelse af det omfangsrige slotsanlæg var spørgsmålet imidlertid, hvad man skulle bruge de store bygninger til. Det glædede skoleudvalget, at Undervisningsministeriet støttede tanken om at placere en statskostskole i slottets bygninger, men på trods af ministeriets støtte opstod der alligevel problemer. Det viste sig nemlig snart, at der på egnen var stemning for at anvende bygningerne til en landbrugsskole, og til dette formål var der allerede rejst en betydelig garantikapital. Desuden mødte tanken om en statskostskole i Augustenborg betydelig modstand i Sønderborg, idet det stod klart, at der ikke samtidig kunne oprettes et gymnasium i Sønderborg, hvis Augustenborg fik en kostskole med gymnasium. På forslag fra Det sønderjyske Ministerium skrinlagde Undervisningsministeriet i sommeren 1919 til stor ærgrelse for skoleudvalget planerne om en kostskole i Augustenborg. ${ }^{7}$

I parentes bemærket gik planerne om en landbrugsskole i Augustenborg også i vasken, idet det lykkedes stærke kræfter i Gråsten at få skolen placeret dér. Så bygningerne på Augustenborg Slot stod tomme til begyndelsen af 1930 'erne, hvor der blev indrettet et hospital for sindslidende. ${ }^{8}$

\section{Forhandlinger i Undervisningsministeriet}

I april og maj 1919 afholdt Undervisningsministeriet en række møder, hvor man drøftede de sønderjyske skolespørgsmål. I drøftelserne deltog foruden nogle embedsmænd fra ministeriet den ministerielle konsulent i sager vedrørende folkeskolen, de to undervisningsinspektører for henholdsvis realskolerne og gymnasieskolerne samt repræsentanter for skoleudvalget. I et par af møderne deltog desuden H.P. Hanssen og Jacob Appel. ${ }^{9}$

Skoleudvalgets forslag til de højere skolers fordeling og placering, som man havde udarbejdet på udvalgets første møde, er givetvis blevet omtalt på disse møder, men egentlige drøftelser af det højere skolevæsen begyndte først i juli måned 1919. Den 10. juli skrev ministeriet til ministeren for Det sønderjyske Ministerium, H.P. Hanssen, at det ville være onskeligt inden længe at have klarhed over, hvorledes statens forhold til de højere skoler i Sønderjylland skulle ordnes. 


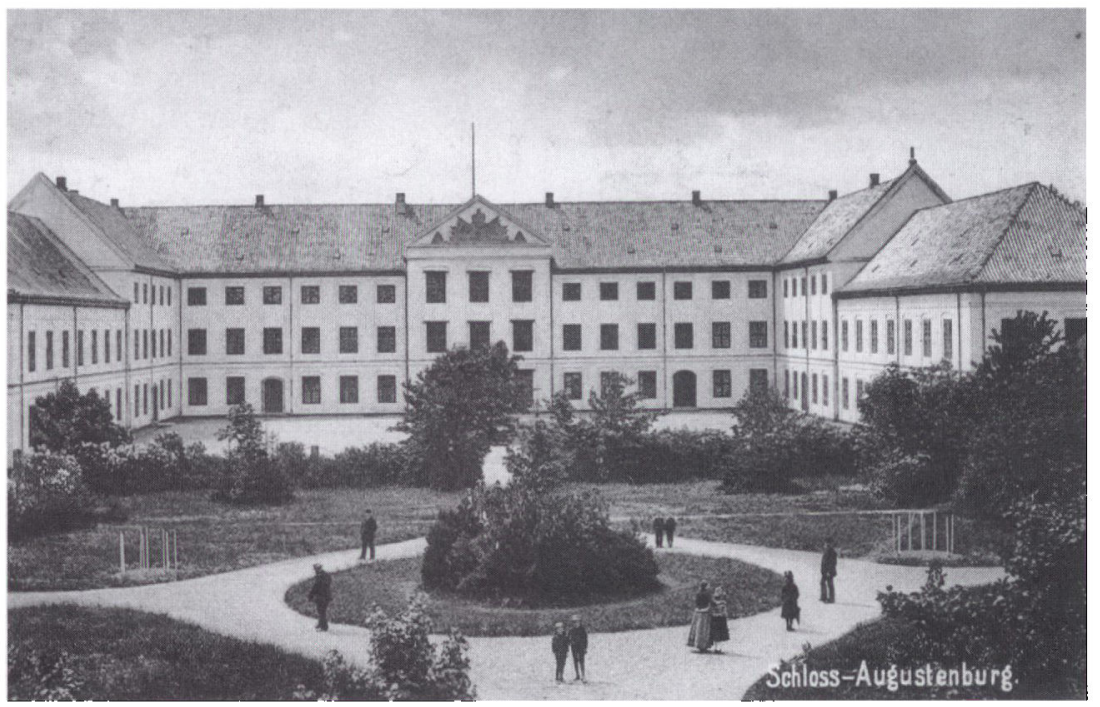

Augustenborg Slot få år for Genforeningen. En overgang var de fornemme bygninger udset til at blive Jyllands forste statslige kostskole. Det ville have varet en kraftfuld dansk manifestation $i$ den tidligere tyske hojborg. Sønderborgerne modsatte sig imidlertid planerne, blandt andet fordi de frygtede, at det ville ske på bekostning af en statsskole $i$ Sonderborg. I sommeren 1919 måtte planerne skrinlægges - til stor ærgrelse for skoleudvalget. Foto: Arkivet ved Dansk Centralbibliotek for Sydslesvig.

Undervisningsministeriet gik ud fra, at det hidtil bestående gymnasium i Haderslev skulle opretholdes, og at der fortsat skulle dimitteres så vel i den nysproglige som i den matematisk-naturvidenskabelige retning, og at undervisningen udelukkende skulle gives på dansk.

Derimod nærede ministeriet nogen tvivl om, hvorvidt der, som foreslået af skoleudvalget, skulle oprettes et tysk gymnasium i Sønderborg. En alternativ løsning gående ud på, at den bygning, der var tiltænkt den tyske skole, i stedet kunne bruges til en dansk kommunal realskole, burde $i$ hvert fald diskuteres, mente ministeriet.

Man var ligeledes i tvivl om, hvorvidt det ville være klogt at følge skoleudvalgets forslag om oprettelse af et gymnasium i Aabenraa. Hvis man bibeholdt den hidtidige realskole i Aabenraa, der da skulle være en dansk realskole, kunne man i stedet søge oprettet et gymnasium i Tønder for børn fra den vestlige del af Sønderjylland. ${ }^{10}$

Den 21. august svarede Det sønderjyske Ministerium, at man kunne tiltræde, at det nuværende gymnasium i Haderslev blev ført videre 
som gymnasium med dansk undervisningssprog. Man var dog af den mening, at der udover den nysproglige og den matematisk-naturvidenskabelige retning også var behov for en klassisksproglig retning, idet man gik ud fra, at der fra hele Nordslesvig ville blive betydelig tilgang af elever, der var interesseret i netop denne retning, for eksempel med et senere teologistudium for øje.

Det sønderjyske Ministerium kunne godt tilslutte sig skoleudvalgets forslag om en dansk realskole i Haderslev. Man anbefalede dog indtrængende, at denne og andre offentligt oprettede realskoler i Sønderjylland blev oprettet som statsskoler. Ministeriet fremførte følgende argumenter herfor: 1) at de nuværende tyske realskoler i Sønderjylland var statsskoler, og at det derfor af befolkningen ville blive opfattet som et tilbageskridt, hvis disse skoler nu blev kommunale, 2) at de bygninger, hvor de pågældende skoler havde til huse, burde bevares til anvendelse for den danske stat, og endelig, 3) at det måtte anses for mere betryggende i national henseende, især i overgangsårene, om også realskolerne blev statsskoler.

Som nævnt ovenfor foreslog Det sønderjyske Ministerium, at planerne om oprettelse af en kostskole i Augustenborg blev taget af bordet, og man foreslog i stedet et dansk gymnasium i Sønderborg. Ministeriet fandt det meget vigtigt, at Sonderborg fik et dansk gymnasium, idet man var bekendt med, at tyske kredse $\mathrm{i}$ byen arbejdede for oprettelse af et tysk gymnasium. Det sønderjyske Ministerium fandt det uheldigt, om den højeste skole i Sønderborg blev en tysk skole. Senere viste det sig imidlertid, at mange tyske elever i Sønderborg ønskede at fortsætte deres skolegang ved et af gymnasierne i Flensborg, så planerne om et tysk gymnasium i Sønderborg måtte skrinlægges. I stedet blev der oprettet et tysk gymnasium i Aabenraa.

I Aabenraa og Tønder foreslog Det sønderjyske Ministerium oprettelse af statsrealskoler.

Med hensyn til spørgsmålet, om der på den danske stats foranledning i Nordslesvig burde oprettes højere skoler med tysk undervisningssprog, mente man i Det sønderjyske Ministerium, at sagen burde stilles $i$ bero, indtil det var afgiort, om Flensborg ville komme til Danmark. Skete det, burde elever, der ønskede optagelse i en højere skole med tysk undervisningssprog, henvises til Flensborg. ${ }^{11}$

I dagene 16.-18. september 1919 afholdt Undervisningsministeriet atter en række møder, hvor man drøftede de sønderjyske skolespørgsmål. I de møder, hvor det højere skolevæsen var på dagsordenen, 
deltog blandt andet undervisningsminister Soren Keiser-Nielsen, to ministerielle embedsmænd, de to undervisningsinspektører, minister H.P. Hanssen samt repræsentanter for skoleudvalget, og her blev det foreløbige udkast til "Forslag til Lov om Oprettelse af Statsskoler i Sønderjylland « forhandlet på plads, $i$ hvert fald hvad angår arten og placeringen af de sønderjyske statsskoler. I udkastet til lovforslaget lagde man sig foreløbig fast på, at der skulle oprettes følgende statsskoler i Sønderjylland: en gymnasieskole i Haderslev, en gymnasieskole i Sønderborg, en realskole i Aabenraa og en realskole i Tønder. Derudover kunne der blive tale om indtil tre gymnasieskoler samt en realskole i Flensborg, såfremt denne by kom under dansk styre. ${ }^{12}$

\section{Lærerspørgsmålet}

Det var naturligvis ikke kun arten og placeringen af de nye statsskoler, som optog ministeriet. Der var også andre vigtige spørgsmål, som trængte sig på, for eksempel lærerspørgsmålet. Vi ved fra diverse ministerielle mødeindkaldelser, ${ }^{13}$ at når lærerspørgsmålet skulle drøftes, sad formanden for Realskoleforeningen og formanden for Gymnasieskolernes Lærerforening med ved bordet, og allerede $\mathrm{i}$ begyndelsen af 1919 må der have været kontakt mellem ministerium og lærerformænd vedrørende lærerspørgsmålet, idet Gymnasieskolernes Lærerforenings medlemsblad Gymnasieskolen i marts 1919, et helt år før lærerstillingerne blev opslået, kunne bringe en artikel om retningslinier for de lærere, der siden hen ønskede at søge til Sønderjylland.

Artiklen er ganske vist skrevet af medlemsbladets redaktør Kjeld Galster, adjunkt ved Kolding højere Almenskole og senere rektor for Aalborg Katedralskole, men man fornemmer tydeligt de ministerielle embedsmænd bag Galsters ord. Der bliver ikke lagt skjul på, at der venter de kommende sønderjyske lærere mange glæder, for eksempel meget interesserede og modtagelige elever, men man henleder især opmærksomheden på de mange vanskeligheder, der utvivlsomt også vil blive. Lærerne må således - især i den første tid - være opmærksomme på, at mange dansksindede familier længe har levet isoleret og helt overladt til sig selv, hvilket kan resultere i visse særheder, som bør tages med nænsomhed og megen forsigtighed, hedder det $i$ artiklen. En anden vanskelighed bliver det faglige. Herom skriver Galster: »Selv danskerne dernede, der dog langt fra har grund til at 
se på den tyske skole med milde øjne, indrømmer, at den fagligt står højt. Det bør derfor være en æressag, at de lærere, der sendes derned, bliver af en - også fagligt set - så god kvalitet, at de ikke står tilbage for de tyske. $O g$ så vil der nok $\mathbf{i}$ de nye gymnasieskoler blive en del tysksindede elever. Disse vil i begyndelsen stå mistænksomme og uvillige over for den nye danske skole, og det regnes for en selvfølge, at alle i det nye lærerkorps vil ofre meget tid på de tysksindede elever, så de hurtigt kan få en positiv indstilling over for alt det nye.

Og der opsummeres sidst $i$ artiklen: Når stillingerne ved de højere skoler i det genvundne land til sin tid skal besættes, vil der ud over særdeles gode faglige kvalifikationer blive lagt stor vægt på menneskelig forståelse, indsigt og besindighed. Derudover vil det være et ufravigeligt krav til det lærerkorps, der sendes til Sønderjylland, at de pågældende ikke kun er fyldt af kærlighed til dansk, men også blottet for had til tysk.

\section{Ministeriets ansættelsespolitik}

Det interessante ved den ovenfor omtalte artikel er, at vi her bliver gjort bekendt med, hvilke egenskaber ministeriet vil tillægge størst betydning, når man senere skal udpege lærere til de fire sønderjyske statsskoler. Som det fremgår af artiklen, ønskede ministeriet lærere, der var udjævnende og forsonende, og man ville for alt $i$ verden undgå lærere, der ved deres optræden virkede nationalt ophidsende. Man ville stille krav om en personlig kultur og takt, så de nye statsskolers lærere kunne repræsentere Danmark på en værdig måde.

Det var sporene, der skræmte. Man huskede stadig, hvor kraftigt den tysksindede del af befolkningen i Mellemslesvig havde reageret, da sprogreskripterne i begyndelsen af 1850'erne gjorde dansk til officielt undervisningssprog $i$ folkeskolen, og man huskede ligeledes, hvordan det preussiske styre efter 1864 havde forsyndet sig over for de nordslesvigske forældre og deres børn ved at gennemtvinge en fortysket skole, hvor der blev slået hårdt ned på alt dansk, hvorved man skabte det allerstærkeste modsætningsforhold mellem tysk og dansk. $^{14}$

Ministeriet ønskede ikke en gentagelse af tidligere tiders fejlslagne skolepolitik. Man ønskede klogeligt at bygge bro mellem de to nationaliteter. Derfor gennemførte ministeriet konsekvent sin anti-konfrontationspolitik, ikke blot lige efter Genforeningen, men også da nazis- 
men siden hen begyndte at vinde frem i mindretallet, ja, selv under besættelsen og efter befrielsen i 1945 holdt man stædigt fast, og som det skulle vise sig, var man parat til at bruge skrappe midler, så som tvangsforflyttelse eller lignende, hvis en lærer undlod at følge ministeriets politik. ${ }^{15}$

\section{Dispensationer}

Da ministeriet stillede krav ud over det sædvanlige til de kommende sønderjyske statsskolelærere, var det nødvendigt, at stillingerne blev gjort så attraktive som overhovedet muligt. Skulle lærerspørgsmålet løses på en tilfredsstillende måde, var man nødt til at ordne forholdene således, at de lærere, der skulle sendes til Sønderjylland, ikke derved kom til at lide økonomiske tab.

Undervisningsinspektøren for gymnasieskolerne, Henrik Bertelsen, gjorde i et brev til ministeriet sidst i marts 1919 opmærksom på problematikken omkring lærerspørgsmålet, som i øvrigt blev yderligere forværret ved, at der i årene 1918-20 var kraftig mangel på gymnasielærere med cand.mag.-uddannelse. Undervisningsinspektøren meddelte i skrivelsen til ministeriet, at han havde været i kontakt med adskillige lærere, som ville være kvalificerede til arbejdet på de sønderjyske statsskoler, men som af økonomiske grunde havde måttet opgive tanken om at søge. Undervisningsinspektøren skrev videre herom: "... Jeg henstiller til det høje ministeriums overvejelse, om det ikke kunne lade sig gøre 1) at der ydes lærerne ved de kommende gymnasieskoler i Slesvig et særligt tilskud til lønningen, 2) at gymnasielærere fra kommunale og private skoler ved ansættelse ved slesvigske statsskoler overfører deres fulde anciennitet fra den kommunale eller private skolevirksomhed. Hvis ikke der gores noget af den art, frygter jeg for, at det vil være umuligt at besætte lærerpladserne ved de slesvigske gymnasieskoler på tilfredsstillende måde, og for så vidt det høje ministerium mener at kunne gå med til foranstaltninger af ovennævnte art, tillader jeg mig at henstille, at disse foranstaltninger bekendtgøres så tidligt som muligt, for at mulige ansøgere i tide kan træffe bestemmelse. ${ }^{16}$

Det problem, som undervisningsinspektøren under punkt to hentydede til, var de paragraffer i statstjenestemandsloven, som foreskrev, at ingen lærere ved private skoler ved ansættelse på en statsskole kunne medtage mere end højst otte års lønanciennitet. Da man måtte 


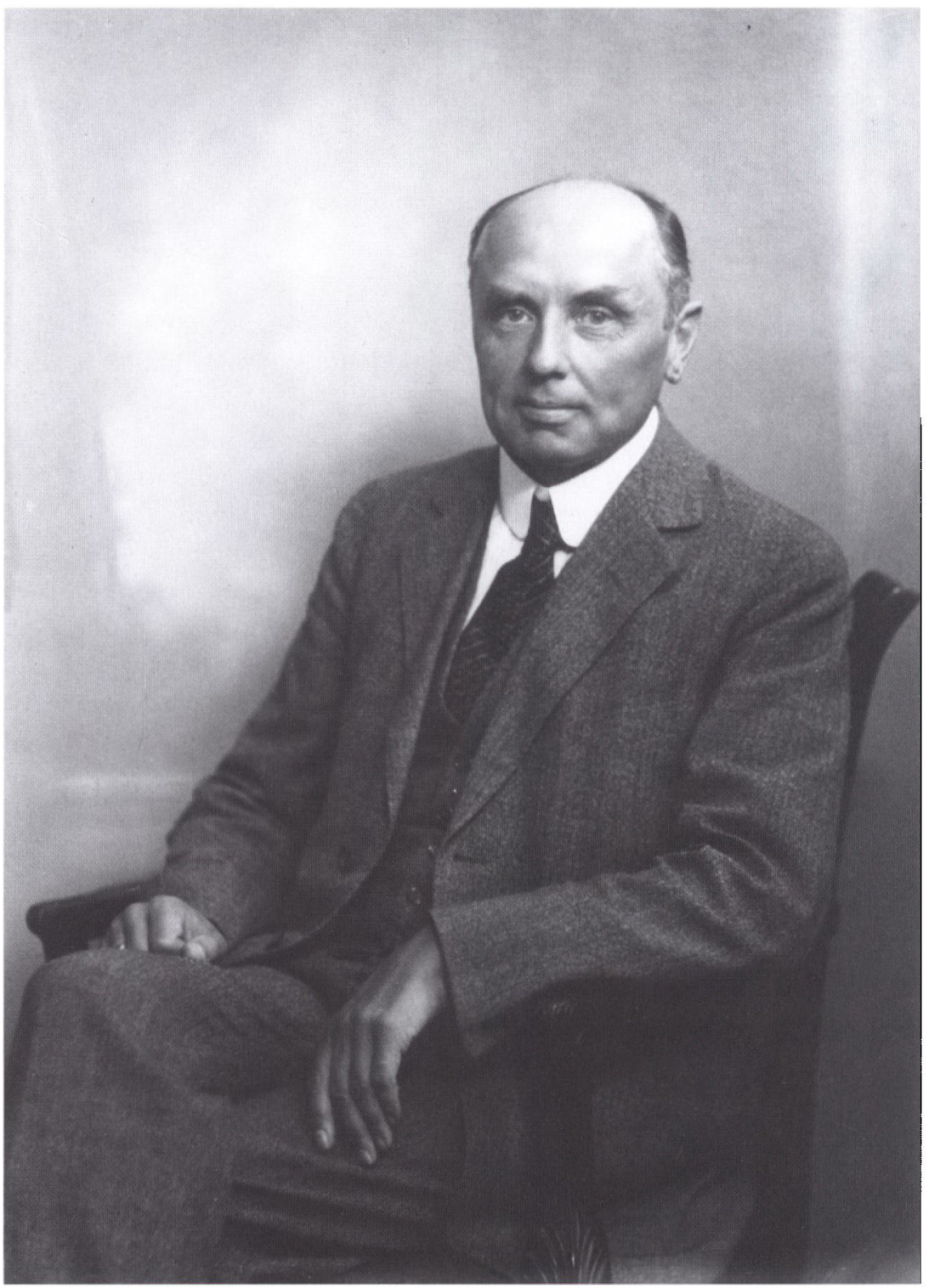

Henrik Bertelsen (1874-1933), dr.phil. Antagelig $i$ begyndelsen af 1920'erne. Efter nogle år som rektor for Roskilde Katedralskole blev Henrik Bertelsen i 1918 udnæevt til undervisningsinspektor for gymnasieskolerne. Bertelsen var den køligt reserverede embedsmandstype med fremragende administrative evner. Som sådan kom han til at spille en afgerende rolle $i$ arbejdet med oprettelsen af de sonderjyske gymnasieskoler. Foto: Portætsamlingen i Det Kongelige Biblioteks Billedarkiv. 
gå ud fra, at en del velegnede og ikke helt unge lærere ved private skoler ville være interesserede $i$ at komme til én af de sønderjyske statsskoler, var det tvingende nødvendigt, at der blev dispenseret her, så de kunne medtage den fulde lønanciennitet og derved undgå en betragtelig lønnedgang.

I ministeriet var man naturligvis helt enig med undervisningsinspektøren i, at der måtte gøres noget ganske særligt for at skaffe gode lærere til Sønderjylland, men man var bestemt ikke begejstret for forslaget om, at der skulle ydes de sønderjyske statsskolelærere et særligt tilskud til lønnen. Derimod kunne man fuldt ud støtte tanken om - $\mathbf{i}$ hvert fald som en overgangsordning på eksempelvis to eller tre år - at lade lærere fra private og kommunale skoler medtage fuld tjenestealder, når de blev ansat ved de sønderjyske statsskoler. Ministeriet var også villig til at søge en dispensation gennemført med hensyn til reglerne om flyttegodtgørelse, således at lærere ved private og kommunale skoler ved ansættelse ved de sønderjyske statsskoler kunne få samme flyttegodtgørelse som de lærere, der kom fra en statsskole. ${ }^{17}$

Ministeriet sørgede for, at disse dispensationer kom med under bemærkningerne $\mathrm{i}$ det tidligere nævnte udkast til "Forslag til Lov om Oprettelse af Statsskoler i Sønderjylland «. I begyndelsen af december 1919 var udkastet færdigskrevet og blev derefter med bemærkninger sendt videre til Rigsdagen, hvor det så skulle behandles med senere ophøjelse til lov for øje.

\section{Rektorstillingerne}

Da ministeriet som nævnt stillede krav ud over det sædvanlige til de lærere, der til sin tid skulle ansættes ved de nyoprettede statsskoler, måtte man selvfølgelig stille endnu skrappere krav til de fire rektorer, der skulle stå i spidsen for skolerne.

I decembernummeret af Gymnasieskolen 1919 blev det meddelt, at rektorstillingerne ved de fire statsskoler i Sønderjylland snarest ville blive opslået. Men de potentielle ansøgere måtte lede forgæves efter stillingsopslaget de kommende måneder, for stik imod gældende praksis havde ministeriet besluttet at undlade at opslå rektorstillingerne. Efter at have underrettet Det sønderjyske Ministerium og skoleudvalget om beslutningen henvendte ministeriet sig i februar 1920 direkte til de fire personer, som man ønskede skulle beklæde rektor- 
embederne, og bad dem indtrængende påtage sig den vanskelige og meget betydningsfulde opgave at lede én af de statsskoler, der skulle oprettes i det genvundne land. ${ }^{18}$

Efterfølgende kunne ministeriet så meddele, at man havde udset sig følgende personer til at overtage ledelsen af de fire statsskoler, som man agtede at oprette i de sønderjyske landsdele:

Som rektor for gymnasieskolen i Sønderborg: Hidtilværende rektor for Svanholm Gymnasium (Schneekloths Skole) i Kobenhavn I.M. Hertz, som rektor for gymnasieskolen i Haderslev: Hidtilværende rektor for Ribe Katedralskole dr.phil. Karl Mortensen, som rektor for skolen i Tønder: Hidtilværende adjunkt ved Metropolitanskolen i København Axel J. West og som rektor for skolen i Aabenraa: Hidtilværende lærer ved Th. Langs skole i Silkeborg cand.theol. et mag. I. Mogensen. ${ }^{19}$

Ministeriet udvalgte altså de nye sønderjyske rektorer. Det var en tilsidesættelse af gældende praksis, men det var ikke en overtrædelse af gældende regler, for kompetencen lå ubestrideligt hos ministeriet. Grunden til, at man valgte ikke at opslå stillingerne, var utvivlsomt, at ministeriet var klar over, at rektorerne ville blive kraftige drivfjedre i den langsigtede genforeningsproces. Man var tilsyneladende helt på det rene med, at et fejlgreb i udvælgelsen af rektorerne kunne få alvorlige konsekvenser for genforeningsarbejdet mange år frem $\mathrm{i}$ tiden.

De fire rektorer var meget forskellige. En enkelt ting havde de dog til fælles: De følte sig hver på deres måde nært knyttet til landsdelen, og de havde alle offentligt - i skrift så vel som i tale - vist stor interesse for den sønderjyske sag. Desuden havde alle fire et indgående kendskab til Sønderjyllands historie og kultur.

Hvad var det for egenskaber hos de fire rektorer, som gjorde, at valget faldt netop på dem? Nedenfor forsøges det især ud fra oplysninger i Undervisningsministeriets og Undervisningsinspektionens arkiver at komme med et bud herpå.

\section{J.M. Hertz}

Jens Michael Hertz var ved udnævnelsen i 192056 år og dermed den ældste af de fire sønderjyske rektorer. Han var også den mest erfarne, hvad skoleledelse angik. Hans undervisningsfag var religion og oldtidskundskab i gymnasiet og geografi i mellemskolen, og han havde 
således ikke - som de øvrige sønderjyske rektorer - tysk som undervisningsfag.

Han var født i Flensborg i 1863, men familien flyttede året efter til København. Hans mor tilhørte en gammel flensborgsk familie, og igennem hele sin barndom og ungdom tilbragte han mange af sine ferier i Flensborg, som han knyttede sig stærkt til, og som han altid anså for den by, hvor han egentlig hørte til. Lige fra de tidligste ungdomsår betragtede han det som den største lykke, hvis han engang kunne få sin gerning i Flensborg.

Hans mor fortalte ham som barn historier fra hans fødeby, især om begivenheder, der stod i forbindelse med de slesvigske krige, og disse sønderjyske fortællinger lagde grunden til hans brændende interesse for Sønderjylland.

Som ung var han usikker på, hvad han skulle vælge som sin levevej: præstegerningen eller lærergerningen. Derfor valgte han det teologiske studium, som endnu i $1880^{\prime}$ erne lod vejen åben i begge retninger. Sideløbende med teologistudiet på Københavns Universitet blev Hertz ansat som huslærer hos lensgreven i det nationalt grebne hjem på Lerchenborg, og de fire år, han var ansat her, overbeviste ham om, at det var lærergerningen, han skulle vælge.

Efter sin teologiske embedseksamen fik Hertz i nogle måneder et værelse på Borchs Kollegium, og dette ophold blev af stor betydning for ham, idet han her kom ind $i$ en kreds af sønderjysk interesserede akademikere, og sammen med dem og andre ligesindede blev han medstifter af den akademiske sønderjyske forening "To Løver«, af hvis bestyrelse han i nogle år var medlem. ${ }^{20}$

I 1889, året efter sin embedseksamen, blev Hertz leder af Frk. P. Friis' Forberedelsesskole for Drenge i København. Frk. Friis tilbød ham selv stillingen, idet hun ønskede at trække sig tilbage, og derved kom han ind $\mathrm{i}$ den bane, der 31 år senere skulle føre ham frem til stillingen som rektor for en af de fire sønderjyske statsskoler. I 1904 forenedes Frk. P. Friis' Forberedelsesskole for Drenge med Schneekloths Skole, hvor Hertz blev medleder, og i 1912 overtog Hertz eneledelsen af skolen, som ifølge et notat $i$ Undervisningsministeriet $i$ Hertz' tid som leder vandt ry som en af hovedstadens bedste. ${ }^{21} \mathrm{Da}$ skolen i 1919 blev overtaget af staten under navnet Svanholm Gymnasium blev skolebestyrer Hertz udnævnt til rektor for denne.

Vi ved, at ministeriet fandt J.M. Hertz selvskreven til en rektorstilling i Sønderjylland, dels fordi han var sønderjyde, og dels fordi han 
"ved sin stilfærdige, myndige og taktfulde fremtræden « havde skabt sig en smuk position i de skoler, som han havde ståt i spidsen for. ${ }^{22}$

Da ministeriet tilbød Hertz et af de sønderjyske rektorater, sagde han straks ja tak. Han bad om at måtte få én af skolerne i Flensborg, såfremt hans fødeby blev dansk, og det lovede ministeriet ham. Til hans store sorg kom Flensborg imidlertid ikke med under dansk styre, men ministeriet gav ham i stedet rektoratet i Sønderborg, den sydligste af de sønderjyske gymnasiebyer. ${ }^{23}$

\section{Mogensen}

Ingvar Mogensen var på mange måder Hertz' diametrale modsætning. Han havde ved rektorudnævnelsen i 1920 overhovedet ingen erfaring som skoleleder, men dette blev opvejet af en imponerende faglig og pædagogisk virksomhed, der i årene op til 1920 havde ført mange ministerielle tillidshverv med sig.

Og netop hans faglig-pædagogiske virksomhed må have vejet tungt, da ministeriet besluttede sig for at tilbyde ham det ene af de sønderjyske rektorater. Ikke mindst i sit bifag tysk stod han stærkt, og han havde erhvervet sig stor indsigt $\mathrm{i}$ tyske skoleforhold. Sin bifagseksamen i tysk havde han suppleret gennem flere studieophold i Tyskland, hvor han blandt andet havde bestået prøver i tysk sprog hos en professor i Marburg. Han havde studeret tyske skoleforhold ved Borgerskolen i Dresden, ved nogle folkeskoler i Mannheim samt ved det klassiske gymnasium i Heidelberg. Sidstnævnte sted deltog Mogensen desuden i det officielle kursus til uddannelse af lærerkandidater. ${ }^{24}$

Ministeriet havde i en årrække fulgt Ingvar Mogensen på tæt hold, ikke mindst via de mange tillidshverv, som han rogtede. Han havde siden 1907 været leder af Statens Tysklærerkursus og her undervist lærere i tysk sprog og litteratur. Han havde i en årrække været beskikket censor ved mellemskole-, real- og præliminæreksamen, og i 1913 blev han medlem af opgavekommissionen for mellem- og realskolerne, lige som han fra 1916-1918 var medlem af eksamenskommissionen for præliminæreksamen. ${ }^{25}$

Ingvar Mogensen var kendt som en streng og alvorlig mand, og han blev aldrig den "pater familias« for sin skole, som tilfældet var med Hertz. Mogensen var sikker på sig selv og aldrig i tvivl om, hvilken vej han ville gå. Han var viljestærk, energisk $i$ alt sit arbejde, religiøst forankret og havde et udpræget nationalt sindelag. 
Han var overbevist om, at en akademisk uddannelse var den bedste indgang til alt kulturelt arbejde. Han omgav sig med en vis distance og fornemhed, som nogle så op til, men som sårede andre, og denne konservatisme $i$ hele hans holdning blev betragtet som det svageste punkt $\mathrm{i}$ hans ellers så stærke rustning. ${ }^{26}$

\section{Karl Mortensen}

Det var uden tvivl et stort ønske i ministeriet at få dr.phil. Karl Andreas Mortensen, rektor for Ribe Katedralskole siden 1918, overtalt til at påtage sig hvervet som rektor for én af de sønderjyske statsskoler.

Han var på udnævnelsestidspunktet i februar 192053 år og havde $\mathrm{i}$ en lang årrække i ministerium og undervisningsinspektion været kendt som en ualmindelig dygtig lærer, såvel fagligt som pædagogisk. Undervisningsinspektøren og dennes faglige medhjælpere betegnede $i$ deres inspektionsrapporter Mortensens undervisning som fortræffelig og brillant, og de roste gang på gang hans elever for at være interesserede, dygtige og ivrige. ${ }^{27}$ Tillidshvervene lod da heller ikke vente på sig. Karl Mortensen havde siden 1907 været medlem af opgavekommissionen for studentereksamen, realeksamen, mellemskoleeksamen og pigeskoleeksamen, og siden 1915 havde han været censor i dansk ved skoleembedseksamen. Desuden havde ministeriet udpeget ham som medlem af udvalgene vedrørende oprettelse af skolenævn og forældrenævn ved statens skoler, og han havde haft sæde i et udvalg, der skulle udarbejde ændringsforslag med hensyn til universitetets tyskundervisning. Karl Mortensen havde udgivet flere lærebøger i sit hovedfag dansk, blandt andet en litteraturhistorie for gymnasiet. ${ }^{28}$

Han havde tysk som bifag og havde desuden foretaget en del både sproglige og pædagogiske studierejser i Tyskland. Karl Mortensen var født og opvokset i Bramdrup ved Kolding et par få kilometer nord for Kongeåen og blev betegnet som frisindet og med dyb forståelse for mennesker og forhold i grænselandet. ${ }^{29}$

\section{A.J. West}

Besættelsen af rektoratet i Tønder kan godt have voldt ministeriet hovedbrud, for netop Tønder, beliggende $\mathbf{i}$ »den truede firkant $«$, stillede med sit store danskfjendtlige flertal og sin afsides, isolerede beliggenhed ganske særlige krav til den kommende statsskoleleder. 


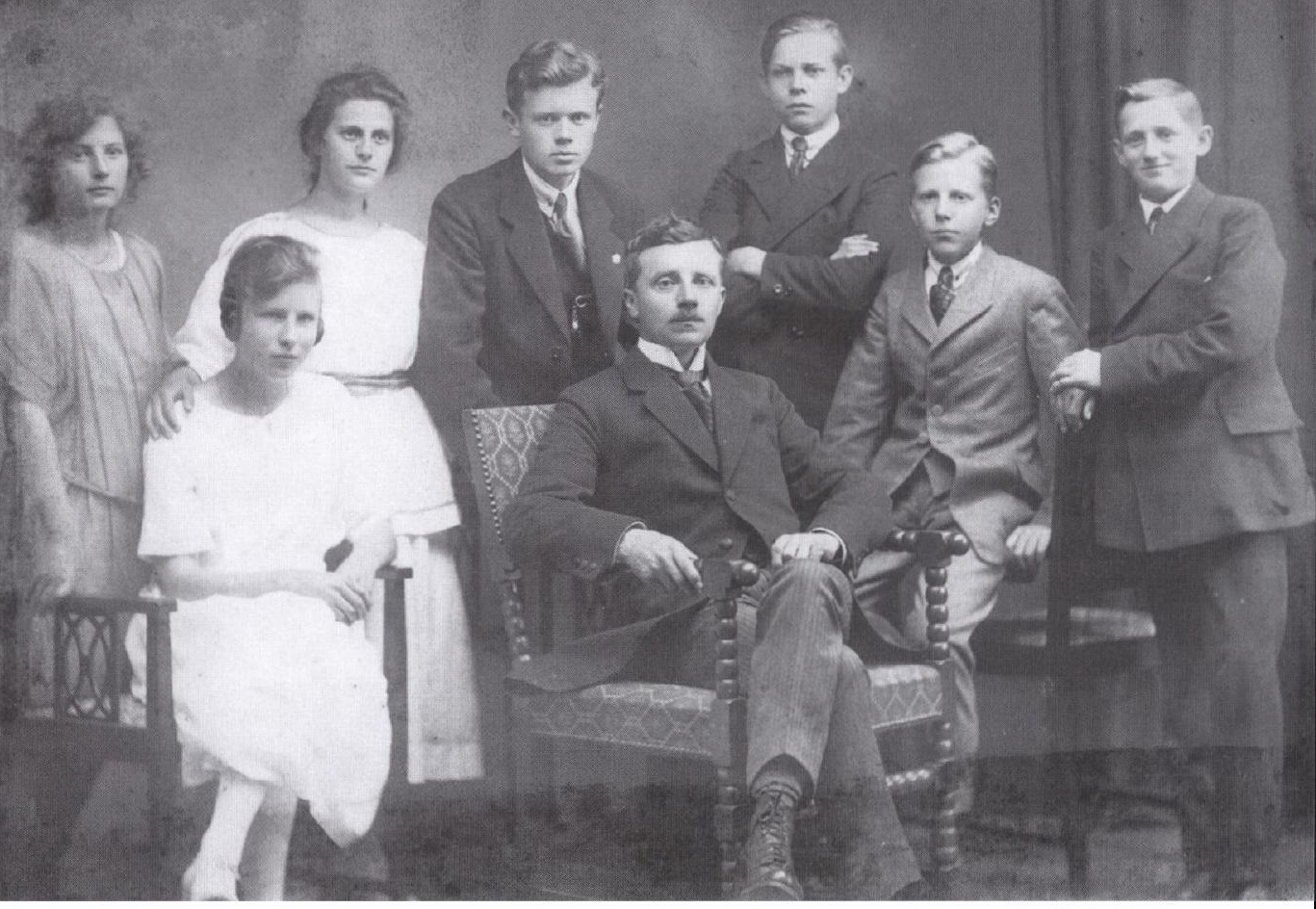

Først $i$ foråret 1923 kunne rektor A.J. West tage afsked med de forste dimittender fra gymnasiet ved Tonder Statssskole. Her ses han året for sammen med syv realister. Foto: Lokalhistorisk Arkiv for Tonder Kommune.

Var der i ministeriet fuld opbakning bag beslutningen om at tilbyde Axel Jürgensen West rektoratet ved Tønder Statsskole? Vi ved det ikke. Vi ved imidlertid, at West $\mathrm{i}$ undervisningsinspektionen var kendt som en dygtig og intelligent lærer. Dog noterede undervisningsinspektøren i én af sine rapporter, at West til tider kunne være tilbøjelig til selv at tale for meget $i$ timerne og at undervise hen over hovedet på eleverne, ${ }^{30}$ og vi ved, at nogle af hans elever fandt ham formel og tør og havde svært ved at komme ham rigtig nær. ${ }^{31} \mathrm{Vi}$ ved også, at undervisningsinspektøren nogle år senere, i 1930, i en indstilling til ministeriet skrev om ham, at hans mangler jo var åbenlyse. ${ }^{32}$ Desværre får vi ikke at vide, hvad undervisningsinspektøren her hentydede til, men man har jo lov til at gatte! Vi ved i hvert fald, at West var barnebarn af den store humoristiske tegner Fritz Jürgensen, $o g$ at han fra sin berømte morfar havde arvet et næsten overdrevent skarpt blik for sine medmenneskers karakteristiske træk samt en lige så overdreven evne til lynhurtigt at finde på særdeles rammende og dækkende øgenavne herfor, en evne som ikke alle opfattede som et decideret positivt træk. ${ }^{33}$ 
Men i ministeriet var man trods alt overbevist om, at West kunne løse den meget vanskelige opgave i Tønder. Han var intelligent, frisindet og respekterede andres meninger og anskuelser, og $i$ en forhandling var han - ofte med stor charme - i stand til at fremføre så overbevisende argumenter, at resultatet af forhandlingerne blev, som West ønskede det.

Han var sønderjyde af fødsel, og hans hjerte bankede for den sønderjyske sag. Han havde nogle år tidligere været med til at oprette den sønderjyske forening "Vidar " og var igennem syv år foreningens meget aktive formand. Både her og $\mathrm{i}$ bestyrelsesarbejde i Studenterforeningen havde West vist sig som en glimrende administrator. $\mathrm{Og}$ så havde han i øvrigt tysk som bifag og beherskede sproget til fuldkommenhed, hvilket var af stor vigtighed netop i det embede, som West blev kaldet til. ${ }^{34}$ Axel J. West var ved udnævnelsen til rektor kun knap 40 år og var dermed den yngste af de fire sønderjyske rektorer.

\section{Instruks for rektorerne}

Sidst i februar samlede ministeriet de fire nye rektorer til et møde, og her blev de orienteret om ordningen af de fire sønderjyske statsskoler efter Danmarks overtagelse af administrationen. Et par uger senere udsendte ministeriet en skriftlig instruks til rektorerne. Den indeholdt dels en kort redegørelse for den påtænkte ordning i overgangsperioden, indtil den tyske skole helt kunne afvikles, dels nogle påbud. Af instruksen fremgik det, at den hidtidige undervisning i de skolebygninger, der efter ferien skulle rumme de danske statsskoler, kunne fortsætte indtil sommerferien, såfremt de tyske lærerkræfter var villige hertil. Ministeriet ønskede allerede sommerferien påbegyndt omkring den 1. juni 1920, så de mange håndværkere kunne få god tid til bygningernes klargøring.

I ministeriet gik man ud fra, at en del tyske elever efter skolernes overgang til danske statsskoler onskede at fuldføre deres skolegang efter den påbegyndte plan og med tysk undervisningssprog. Dette ønske skulle rektorerne imødekomme "inden for rimelige grænser". Den danske stat kunne dog ikke forpligte sig til at skaffe lærere hertil, disse burde rekrutteres fra det hidtidige tyske lærerpersonale, som naturligvis ville blive lønnet af den danske stat med honorarer svarende til de lønninger, som danske lærere i tilsvarende stillinger oppebar. De tyske lærere kunne ikke fastansættes. Hvis tyske lærere kunne 
skaffes, kunne de tyske elever i tre år gøre regning på at fortsætte deres undervisning efter den hidtidige plan og med tysk undervisningssprog. Alle tyske elever skulle have tilbud om undervisning $i$ dansk, således at de efter tre års forløb om muligt kunne overgå til undervisning på dansk.

Ministeriet påpegede dog, at hvis der i en statsskoleby blev oprettet en kommunal eller privat tysk skole af samme art som statsskolen, skulle de tyske elever henvises hertil. Selv om der ikke blev oprettet en kommunal eller privat tysk skole i en statsskoleby, kunne en tysk klasse i den danske statsskole kun oprettes, såfremt der var tilmeldt mindst fem elever til klassen.

For de elevers vedkommende, som efter skolernes overgang til danske statsskoler ønskede at fuldføre deres skolegang med dansk undervisningssprog, skulle rektorerne sørge for, at der blev oprettet det nødvendige antal klasser, så der både blev plads til disse elever og til de nytilkomne, og rektorerne skulle til sin tid til ministeriet indstille, hvilke ændringer de anså for nødvendige med hensyn til disse klassers læsestof og eksamenspensa.

Ministeriet ønskede, at rektorerne fik god tid til forberedelserne på stedet, hvorfor man lovede snarest at frigøre dem for deres forpligtelser på de skoler, hvor de på udnævnelsestidspunktet gjorde tjeneste. Man ønskede, at rektorerne snarest og senest sidst $i$ april tog ophold i den by, hvor de skulle virke. Opholdet behøvede dog ikke i begyndelsen at være permanent, men rektorerne blev pålagt hurtigst muligt at meddele deres træffetider i de lokale aviser, så de forældre, som måtte ønske det, kunne møde op og få oplysninger vedrørende den fremtidige skoleordning. ${ }^{35}$

\section{Rektorernes rejse til Sønderjylland}

Den 6. marts 1920 skrev ministeriet til de sønderjyske rektorer, at de den 24. marts og følgende dage skulle deltage i en studierejse til de fire sønderjyske byer, hvor der efter Genforeningen skulle oprettes statsskoler. $^{36}$

I rejsen deltog - foruden de fire rektorer - fra Undervisningsministeriet kontorcheferne, de senere departementschefer, Kai Glahn og Fr. Graae samt fuldmægtig Aage Barfod, fra Det sønderjyske Ministerium fuldmægtig Oluf Skjærbæk, fra Undervisningsinspektionen undervisningsinspektørerne $\mathrm{H}$. Bertelsen og F. Rønning samt den kgl. 
bygningsinspektør fra Odense. Da man havde passeret grænsen, kom flere til, bl.a. H.P. Hanssen og højskoleforstander Jacob Appel. Formålet med rejsen var at præsentere rektorerne for deres respektive skoler, se på skoleforholdene samt lære befolkningen og dens ønsker at kende. Hvad det sidste angik, skulle netop den på rejsen etablerede kontakt mellem de danske skolemyndigheder og befolkningen vise sig at blive betydningsfuld. ${ }^{37}$

På det tidspunkt, hvor rejsen fandt sted, var det som nævnt besluttet at oprette to statsgymnasier, i Haderslev og i Sønderborg, samt to statsrealskoler, i Aabenraa og Tønder, men mødet med befolkningen i Aabenraa og Tønder afslørede et stærkt ønske om også at få gymnasier dér. Det var naturligvis ikke muligt for embedsmændene i Undervisningsministeriet på stedet at tage stilling til det ønske, men befolkningens repræsentanter blev opfordret til at sende et andragende til ministeriet, såfremt de var utilfredse med de trufne beslutninger.

\section{Udvidelsen godkendes}

Allerede den 27. marts 1920 sendte en række dansksindede mænd i Tønder til ministeriet, hvad der siden hen blev kaldt $"$ Tønderadressen «: »Vi undertegnede beboere af Tønder by og amt andrager ærbødigst det højtærede Undervisningsministerium om ved Genforeningen at udvide Tønder Realskole til et gymnasium «. I skrivelsen blev det påpeget, at den daværende realskole havde et større opland end nogen anden af de højere skoler i Sønderjylland, og at det store opland havde brug for en skole, der førte frem til studentereksamen. Befolkningen havde flere gange anmodet den preussiske regering om en udvidelse af realskolen, men uden resultat. Man håbede derfor inderligt, at den danske stat nu ville opfylde dette krav. Man slog endvidere på, at der intet steds overhovedet kunne forventes en sådan strid mellem dansk og tysk som netop i Tønder, hvorfor det ville være af stor national betydning, at den danske højere skole i Tønder kunne blive så fuldkommen som muligt, så den også kunne drage børn af tysksindede forældre til sig. Efter til sidst at have pointeret, at der i den nuværende statslige realskoles bygning ville være tilstrækkelig plads til den ønskede udvidelse, sluttede skrivelsen således: "I henhold til foranstående beder vi det højtærede ministerium om at tage dette vort andragende under velvillig overvejelse.« Underskriverne på adressen var ifølge kontorchef Martin Hammerich i Det 


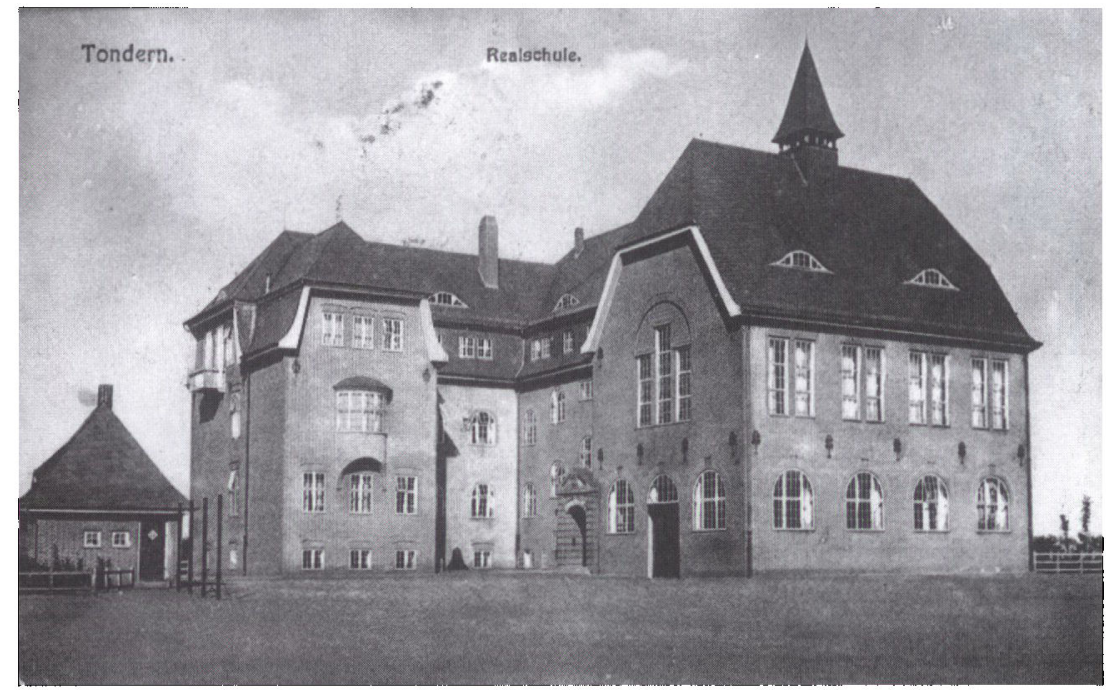

Postkort med Tonder Statsskoles bygninger, som de så ud ved overdragelsen. Den 25. august 1920 abnede skolen som dansk statsskole. Ved abningen var der 88 elever. Først ved en overenskomst af 15 . oktober 1920 blev bygningerne formelt overdraget fra Tonder Kommune til den danske stat. Foto: Arkivet ved Dansk Centralbibliotek for Sydslesvig.

sønderjyske Ministerium en særdeles alsidig repræsentation for danskheden i det vestlige Nordslesvig. ${ }^{38}$

Nogle dage senere indsendte en række beboere i Aabenraa en lignende skrivelse til ministeriet $\mathrm{om}$ at få den planlagte statsrealskole udvidet til et gymnasium.

I ministeriet kom tanken om at udvide de to statsrealskoler til gymnasieskoler ikke bag på embedsmændene. Allerede i sommeren 1919 må man i ministeriet have diskuteret, hvordan man skulle stille sig, hvis forholdene skulle gøre det nødvendigt at udvide realskolerne med en gymnasieafdeling, for den 30. september 1919 spørger undervisningsinspektøren for gymnasieskolerne, Henrik Bertelsen, i et brev til ministeriet, om det ikke ville være godt, om man i lovforslaget kunne gøre følgende tilføjelse: "Realskolerne i Aabenraa og Tønder kan, for så vidt forholdene taler derfor, udvides med en gymnasieafdeling. « ${ }^{39}$ Denne tilføjelse ønskede ministeriet imidlertid ikke, men sagen har altså forud været diskuteret. Og ved behandlingen af lovforslaget om oprettelse af statsskoler i Sønderjylland i Rigsdagspartiernes sønderjyske Udvalg den 10. december 1919 bemærkede under- 
visningsminister Søren Keiser-Nielsen, at det var tanken med de to sønderjyske statsrealskoler, at såfremt der skulle vise sig behov derfor, ville disse med tiden kunne udvides med en gymnasieafdeling, men rundede dog af med at sige, at det sandsynligvis ikke ville blive aktuelt foreløbig. ${ }^{40}$

Straks efter hjemkomsten fra rejsen til Sønderjylland følte undervisningsinspektøren for gymnasieskolerne, Henrik Bertelsen, sig dog nødsaget til den 30 . marts 1920 at indsende en indtrængende opfordring til ministeriet (fremhævelserne er brevskriverens egne): "Efter det foreløbige lovforslag om ordningen af den højere skole i Nordslesvig skal der oprettes danske statsgymnasieskoler i Haderslev og Sønderborg, men i Aabenraa og Tønder statsrealskoler, som eventuelt senere kan udvides med gymnasieafdeling, og for at forberede en sådan udvidelse skal der ved disse skoler ansættes adjunkter, som er kvalificerede til at overtage gymnasieundervisning. Jeg henstiller indtrængende til ministeriet at foranledige, at også statsskolerne $i$ Aabenraa og Tønder straks gøres til gymnasieskoler, dog kun med en enkelt gymnasielinie.« Ansøgningsfristen til embederne ved de fire statsskoler (se nedenfor) var udløbet midt i marts, og undervisningsinspektøren havde øjensynlig allerede her et par uger efter ansøgningsfristens udløb gennemgået alle ansøgningerne og kunne derfor i brevet til ministeriet fremkomme med argumenter, som ikke sådan uden videre kunne fejes af bordet: "Til embederne ved de planlagte danske højere skoler i Nordslesvig er der indkommet ca. 260 ansøgninger. De fleste af ansøgerne er ganske ukvalificerede til at undervise i gymnasieskoler, og af dem, som er kvalificerede til gymnasieskoleundervisning, har kun et så ringe tal søgt til Tønder og Aabenraa, at - medens det vil være muligt at besætte gymnasieskolerne i Haderslev og Sønderborg med et fuldt kvalificeret lærerpersonale -, så vil det være umuligt på grundlag af de foreliggende ansøgninger at danne et lærerpersonale ved Tønder og Aabenraa statsrealskoler af en sådan art, at det kan tilfredsstille en gymnasieskoleundervisnings krav.«

Undervisningsinspektøren anførte videre, at når så få adjunkter havde søgt til Tønder og Aabenraa, skyldtes det, at lærere, der var uddannet til at undervise gymnasieklasser, naturligvis ville virke ved gymnasieskoler, og da der på det tidspunkt var mangel på gymnasielærere, var ingen af konkurrencemæssige årsager tvunget til at søge embede ved realskoler. $\mathrm{Og}$ undervisningsinspektøren slog fast: "Skal 


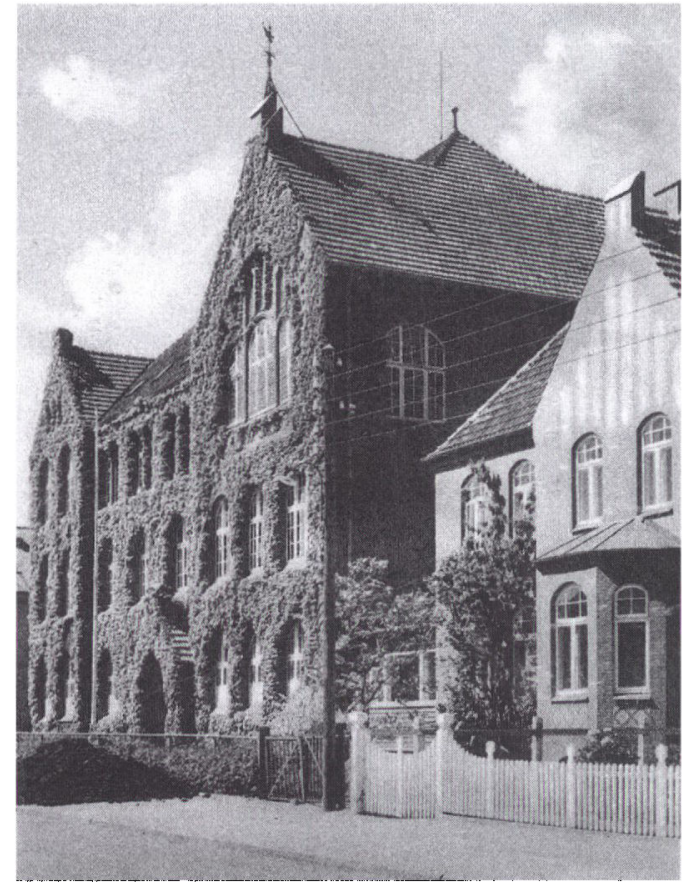

I Aabenraa indrettedes Statsskolen $i$ den tidligere drengeskole »Königliche Preussische Realschules « bygninger fra 1905. Oprindelig var der planer om at fore skolen videre kun som realskole. Når skolen i Aabenraa alligevel blev udvidet med en gymnasieskole, skyldtes blandt andet frygten for, at det tyske mindretal ville oprette et gymnasium $i$ byen. Åbningen af Aabenraa Statsskole fandt sted den 23. august 1920 med 141 elever, heraf langt de fleste realskoleelever. Allerede $i$ foråret 1921 kunne man fejre den forste sproglige dimittend fra gymnasiet. Aret efter var der to. Foto: Arkivet ved Dansk Centralbibliotek for Sydslesvig.

statsrealskolerne være rustede til at udvides med gymnasieafdelinger, må det store flertal af lærere være kvalificerede til at overtage gymnasieundervisning. Kun ved straks at gøre de to skoler til gymnasieskoler kan man vente at få et til gymnasieundervisning fuldt egnet lærerpersonale." Undervisningsinspektøren kom derefter ind på spørgsmålet om forholdet mellem tyske og danske skoler i de to byer og sluttede efter en lang redegørelse herom sin henstilling til ministeriet således: "Den mulighed er ikke udelukket, at man vil tænke på oprettelsen af en tysk gymnasieskole i Nordslesvig, og en sådan skole vil man antagelig lægge i Aabenraa eller Tønder. Grundlaget for planer i den retning bliver afgjort svagere, når der i disse byer findes danske gymnasieskoler. Ud fra disse betragtninger skal jeg da indtrængende henstille, at de påtænkte statsrealskoler i Aabenraa og Tønder straks gøres til gymnasieskoler. Det vil være unødvendigt at oprette mere end én gymnasielinie, og da skolerne skal være fællesskoler, anser jeg det for rigtigst, at de får den nysproglige linie. ${ }^{41}$

I Undervisningsministeriet fandt man undervisningsinspektørens argumenter så tungtvejende, at man blev overbevist om, at det allige- 
vel ville være rigtigst at gennemføre den påtænkte udvidelse straks, og ministeren sørgede derefter for de bevilgende myndigheders tilslutning. Den 12. maj 1920 godkendte Rigsdagspartiernes sønderjydske Udvalg enstemmigt det ændrede lovforslag. Efter at det ligeledes enstemmigt var blevet vedtaget i Rigsdagen, blev det den 30 . juni 1920 underskrevet af Kongen. Begyndelsen af loven kom nu til at lyde: „Undervisningsministeren bemyndiges til i de sønderjydske landsdele at oprette en statsgymnasieskole $i$ hver af de følgende byer: Haderslev, Aabenraa, Sønderborg og Tønder. Der oprettes ved hver skole så mange gymnasielinier, som af ministeren skønnes fornødent. $\ll^{42}$

I de fleste beretninger om de to statsrealskolers udvidelse til gymnasieskoler i 1920 kan man læse, at udvidelserne skyldtes det massive ønske fra befolkningen $\mathrm{i}$ Tønder og Aabenraa, som mødte embedsmændene og rektorerne på studierejsen i Sønderjylland sidst i marts 1920. Det er ikke rigtigt! I hvert fald er det ikke hele sandheden. Man skal naturligvis ikke undervurdere betydningen af de henvendelser, som borgerne i Tønder og Aabenraa indsendte til ministeriet, men æren, for at udvidelsen blev en realitet i 1920, må tilfalde den fremsynede undervisningsinspektør Henrik Bertelsen. Havde han ikke støttet sagen så varmt, og havde han ikke over for ministeriet argumenteret så kraftigt og overbevisende for sagen, ville udvidelsen af de to statsrealskoler ikke være blevet effektueret allerede i 1920 .

\section{Læreransøgningerne}

Som nævnt blev lærerstillingerne opslåt i marts 1920. Opslaget kom den 2. marts, og ansøgningsfristen var på kun 14 dage, men blev dog et par dage før udløbet forlænget med tre dage. Til de to gymnasieskoler søgte man lektorer, adjunkter og andre lærere og til de to realskoler adjunkter og andre lærere, ${ }^{43}$ men da udvidelsen af de to realskoler blev en realitet, var et nyt stillingsopslag nødvendigt. Det kom den 15. maj med en ansøgningsfrist på kun en uge, og i det supplerende opslag meddeltes det, at man på grund af udvidelsen ud over adjunkter og andre lærere nu også søgte lektorer til skolerne i Tønder og Aabenraa. ${ }^{44}$

Ifølge brevet af 30. marts 1920 fra undervisningsinspektøren til ministeriet indkom der ved stillingsopslaget i marts $1920 \mathrm{ca} .260$ an- 
søgninger. Antallet blev dog forøget med ca. 30 i løbet af april. Ved det supplerende opslag i maj modtog ministeriet så yderligere ca. 25 ansøgninger, men størstedelen af disse ansøgere var gengangere, som blot meddelte, at de også var villige til eventuelt at modtage ansættelse ved skolerne $\mathrm{i}$ Tønder eller Aabenraa nu, hvor disse var blevet udvidet med en gymnasieafdeling. ${ }^{45}$

Det var en meget forskelligartet ansøgerskare, der søgte om embede ved de sønderjyske gymnasieskoler. Der var eksempelvis en adjunkt fra Viborg, en cand.mag. ansat i en kommunelærerindestilling i folkeskolen, en professor i Naumburg, en jysk sognepræst, en kvindelig dr.phil., to lærere fra Kiel, en oversergent ved Gardehusarregimentet, en professor fra Bremen og en lærer fra Thisted. ${ }^{46}$

$\mathrm{Og}$ ansøgernes bevæggrunde for at søge embede ved det højere skolevæsen i Sønderjylland var også meget forskellige. En del ansøgere søgte til det genvundne land, fordi de enten var født i landsdelen, fordi deres slægt stammede fra Sønderjylland, eller fordi de på anden måde følte sig knyttet til denne del af landet. En overlærerinde, født i Vojens og ansat ved et pigegymnasium i Tyskland, skrev sådan: »Det er mit håb, at det høje ministerium vil give mig som født sønderjyde en ansættelse i mit hjemland, så at ikke jeg som den eneste af min slægt efter Genforeningen må blive tilbage i Tyskland ...«, og en anden ansøger, også ansat ved en skole i Tyskland, indledte sin ansøgning således: "Da nu det, vi sønderjyder næsten ikke har turdet håbe på, synes at skulle blive til virkelighed, vort hjems genforening med Kongeriget, er det mit højeste ønske at kunne vende hjem til mit fødeland ..... En mellemskolelærerinde i Lyngby ansøgte om embede, fordi en del af hendes slægt var hjemmehørende i Sønderjylland, og fordi det var hendes varmeste ønske at komme til at arbejde med danskhedens genrejsning i Sønderjylland. ${ }^{47}$

En adjunkt ansat ved et jysk gymnasium havde siden sin tidligste ungdom følt stor interesse for den sønderjyske sag og havde som student flere gange været på vandreture i Sonderjylland, hvilket yderligere havde styrket hans interesse $i$ en sådan grad, at han i sin hjemby havde stiftet en lokal afdeling af $\gg$ De samvirkende sønderjydske Foreninger «. Nu ville han gerne fortsætte arbejdet for den sønderjyske sag ved at virke blandt den opvoksende slægt i det genvundne land. Og en lærer i Horsens, hvis tanker fra barnsben havde været knyttet til Sønderjylland, havde livet igennem fulgt levende med i alt, hvad der foregik i landsdelen, og udtrykte nu et stærkt onske om at 
få lov til at udføre et arbejde dernede. Hertil kom en gruppe ansøgere, der ønskede embede i Sønderjylland, fordi de fandt arbejdet i et grænseland interessant og tillokkende, og fordi de gerne ville opleve en grænseflytning i praksis. En lærerinde skrev således: »Det vil være mig en glæde at være med i den skolegerning, der i de nye tider skal føre dansk sprog, dansk opdragelse og dansk folkeliv i sin bedste skikkelse ind i landet, som vender tilbage, og det er mit håb, at jeg inden for en skoles kreds må prøve at yde et arbejde, der stiler mod dette mål. « $^{48}$

Og så var der den lille gruppe af lærere, der søgte til Sønderjylland, fordi de af forskellige årsager var kørt fast $\mathrm{i}$ deres hidtidige embede og onskede at begynde et nyt liv med nye udfordringer. Eksempelvis søgte en lærer ved et gymnasium i en sjællandsk købstad om embede i Sønderjylland, fordi han efter et nyligt opløst ægteskab ønskede at begynde forfra blandt nye mennesker. ${ }^{49}$

\section{Besættelse af lærerembederne}

Da den sidste ansøgningsfrist var udløbet den 22. maj 1920, opgjorde undervisningsinspektøren antallet af ansøgninger til ca. 300. De fleste af disse blev dog øjeblikkeligt lagt til side, idet ansøgerne efter undervisningsinspektørens mening manglede de nødvendige faglige forudsætninger.

Den resterende del af ansøgningerne modtog rektorerne derefter på skift med opfordring til meget hurtigt at gennemlæse dem og til senere brug notere, hvilke ansøgere de kunne onske ansat på deres skole.

Sidst i maj blev rektorerne enkeltvis kaldt til møde i København vedrørende læreransættelser ved deres skole. Møderne blev ledet af undervisningsinspektor Henrik Bertelsen, og som bisidder deltog kontorchef Kai Glahn fra Undervisningsministeriets 2. departement, hvorunder sager vedrørende det højere skolevæsen hørte. På disse møder blev alle ansøgningerne gennemgået. Til slut enedes man om, hvilke lærere rektorerne i deres indstilling til ministeriet skulle ønske ansat. ${ }^{50}$

Antallet af lærere ved de fire statsskoler blev på møderne fastsat på grundlag af det klassetal, som man med sikkerhed kunne regne med. Når antallet af lektorer var væsentlig mindre for Tønder og Aabenraa statsskolers vedkommende, skyldtes det, at man i de to 
skolers gymnasieafdelinger kun oprettede en enkelt retning, nemlig den nysproglige, hvorimod der $\mathbf{i}$ Haderslev var tre retninger og $\mathrm{i}$ Sønderborg to. Dertil kom, at der i Tønder kun blev oprettet én gymnasieklasse i 1920, naturligvis $1 \mathrm{~g}$. Her blev gymnasieafdelingen altså først fuldt udbygget med både 2. og 3. g i skoleåret 1922/23. Alle fire steder blev der naturligvis realklasser oven på mellemskolen. Beregningerne af lærertallet blev foretaget ud fra den formodning, at lærerne ikke underviste synderligt ud over det pligtige timetal.

Efter mødernes afslutning fik rektorerne besked på derhjemme hurtigt at foretage en prøveopstilling af fag- og timefordelingen med det på møderne aftalte lærerpersonale og dermed sikre sig, at de nødvendige lærerkræfter - og ikke flere - var til rådighed.

Efter at undervisningsinspektøren havde fået besked om, at regnestykket på alle fire skoler var gået op, kunne han meddele ministeriet, at det på maderne var blevet aftalt at ansætte:

\begin{tabular}{lcccc}
\hline & Lektorer & Adjunkter & Andre lærere & I alt \\
\hline Haderslev: & 9 & 5 & 2 & 16 \\
Aabenraa: & 3 & 6 & 3 & 12 \\
Sønderborg: & 7 & 5 & 2 & 14 \\
Tønder: & 3 & 7 & 2 & 12 \\
\hline & 22 & 23 & 9 & 54 \\
\hline
\end{tabular}

Undervisningsinspektøren beklagede sig over, at det havde været vanskeligt at få tilstrækkelig mange dygtige lærere i tysk og i fysik/ kemi samt at få dygtige lærerinder til de embeder, to ved hver skole, der nødvendigvis måtte besættes med kvinder, men "som helhed har jeg dog grund til at tro, at de fire skoler får et dygtigt lærerpersonale, og at de vil kunne stå mål med gennemsnittet af de bedste blandt de gamle statsskoler. « ${ }^{51}$

Kontorchef Kai Glahn kunne til sine foresatte, departementschef og minister, om læreransættelserne meddele, at sindstillingen er sket efter omhyggelige og langvarige fællesforhandlinger mellem $\mathrm{dr}$. Bertelsen og rektorerne. Jeg overværede disse forhandlinger og har indtryk af, at det foreliggende resultat er godt og er dikteret af nøje hensyntagen til sted og personer. Der er foreslået 22 lektorer, 23 adjunkter og 9 andre lærere. Efter den ved de gamle skoler fulgte 
Kai Glahn (1875-1925), cand. jur. Antagelig omkring 1915. Kai Glahn blev $i 1900$ ansat $i$ ministeriet for Kirke- og Undervisningsvæsenet. Han var den myndige og energiske embedsmandstype og steg hurtigt $i$ graderne. Ved oprettelsen af Undervisningsministeriet $i$ 1916 blev han udnæont til kontorchef. Som leder af 2. departements 1. kontor fungerede Kai Glahn i årene 1918-20 som ministeriets repræsentant i forhandlingerne om oprettelse af de senderjyske statsskoler. I 1921 blev Glahn udnæont til departementschef - en stilling han bestred indtil sin pludselige død i 1925. Foto: Portrætsamlingen $i$ Det Kongelige Biblioteks Billedarkiv.

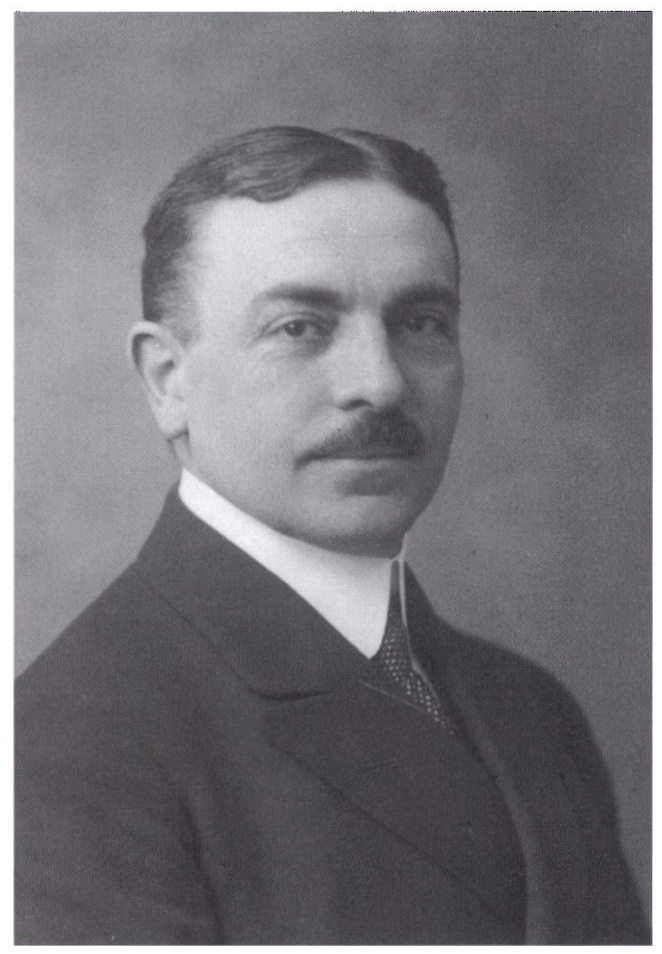

regel (2 lektorer til 3 adjunkter) er det jo et stort lektorat, men den sønderjyske lov stiller ministeren frit i så henseende, og der er ingen tvivl om nødvendigheden af et så stort tal, det er nemlig ikke lutter idealisme, der har bragt ansøgerne frem. ${ }^{52}$ For øvrigt svarer lektortallet jo temmelig godt til 2/5 af det samlede lærertal, nemlig 22 lektorer af 54 lærere. $\ll^{53}$

Når der ved åbningen af de fire skoler i august/september 1920 var ansat flere lærere, end tallene ovenfor angiver, skyldes det, at de fortrinsvis tyske - lærere, der blev ansat til midlertidigt at varetage undervisningen i de tyske afviklingsklasser, ikke var medregnet i de anforte tal. Dertil kom, at tilstrømningen til de nye statsskoler generelt var langt større end forudset, så det i sommerens løb havde været nødvendigt at ansætte et par lærere mere. Og da tilstrømningen, især i Sønderborg og Tønder, fortsatte efter skolernes åbning, var man nogle uger inde i skoleåret nødt til at dele et par klasser, hvilket nødvendiggjorde flere læreransættelser. 


\section{Reaktioner}

I løbet af juni måned udsendte ministeriet besked til de udpegede lærere om deres ansættelse pr. 1. august 1920 . Vi ved, at disse breve skabte stor glæde i mange hjem, ja, for nogles vedkommende $i$ en sådan grad, at modtagerne straks måtte gribe pen og papir og sende ministeriet en takkeskrivelse, fordi de var kommet $i$ betragtning. En adjunkt ved Marselisborg Gymnasium, som fik sit ønske om ansættelse ved Aabenraa statsskole opfyldt, takkede ministeriet med disse ord: "Med stor glæde og inderlig tak modtog undertegnede i går brev nr. 9136, journalnr. 562/1920. Gud give nu kræfter og evner, som jeg har vilje, at arbejdet må blive til gavn for fædrelandet. $\aleph^{54}$

Ministeriet udsendte ikke meddelelse om afslag på ansøgninger, men efterhånden som det rygtedes, at de udpegede lærere havde modtaget besked, blev det klart for de øvrige, at de var blevet vraget. For nogle var skuffelsen og vreden så stor, at også de med det samme måtte gribe pen og papir og skrive til ministeriet: "Jeg er af en god dansk familie, føler og tænker selv dansk, og min fader yder et stort arbejde i kampen for danskheden i Slesvig. Hos mine fjender har jeg høstet anerkendelse, derfor harmer det mig dobbelt dybt hos danskerne at møde det modsatte. Det er jo dog os sønderjyder, der med utallige ofre, savn og store tab har holdt ud hernede og vundet sejren ...« skrev Sophie v. Lachmann, der ikke fik sit ønske om en stilling i Sønderjylland opfyldt. I hvert fald ikke i første omgang. Med til historien hører nemlig, at hun - på baggrund af sin klage - alligevel kom i betragtning, da man i efteråret 1920 på Aabenraa Statsskole på grund af stadig tilgang af elever var nødt til at ansætte endnu en lærer. Og dermed indledtes et påskønnelsesværdigt virke, der skulle vare $\mathrm{i}$ hele 36 år! $!^{55}$

\section{Forberedelse og åbning}

I midten af april 1920 tog de fire rektorer ophold i deres respektive byer, og der var masser af ting at ordne. Ministeriet ønskede, at rektorerne udarbejdede og indsendte en plan over de nødvendige reparationer. De fleste steder var bygningerne temmelig miserable, idet de ikke var blevet vedligeholdt gennem krigsårene, og dertil kom, at de tyske skoler havde været rene drengeskoler med færre klasser. Derfor måtte rummene udnyttes bedre, i flere tilfælde deles, og det kneb 


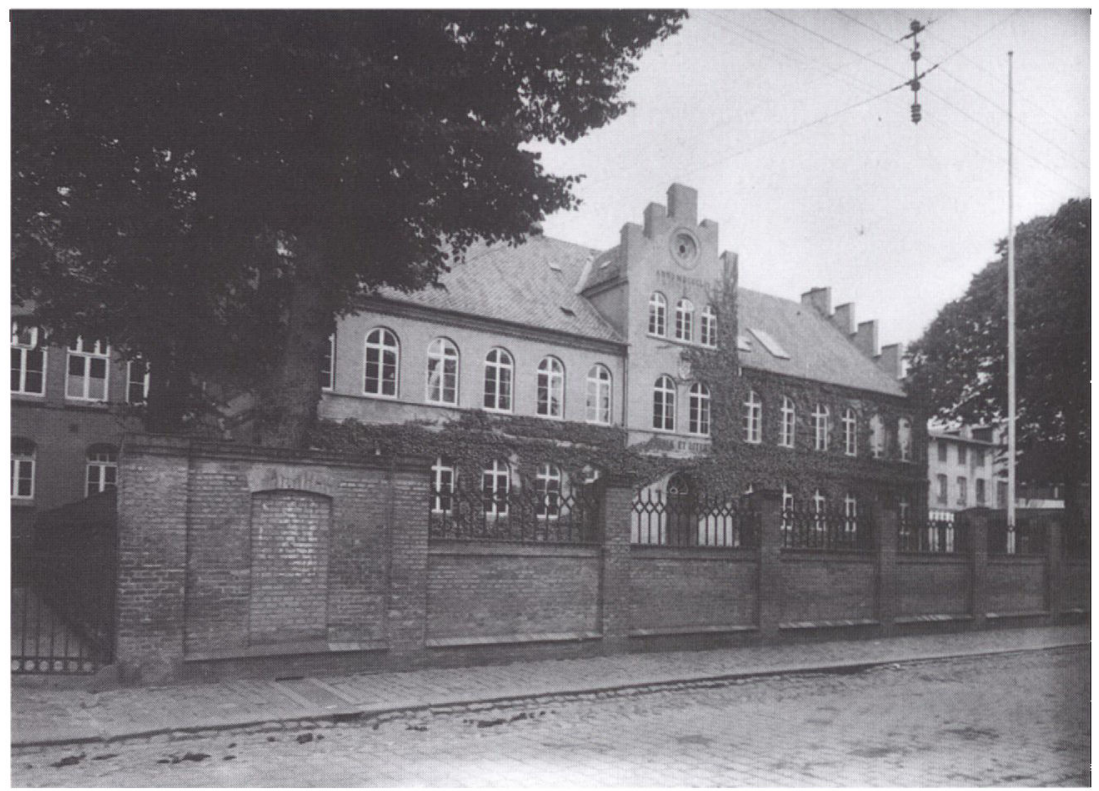

Haderslev Katredalskole omkring 1930. På grund af omfattende reparationsarbejder på bygningerne $i$ Haderslev åbnede skolen her to uger senere end planlagt, nemlig den 7. september 1920. Bygningerne var efter verdenskrigen $i$ så dårlig forfatning, at kontorchef $i$ Undervisningsministeriet, Kai Glahn, ved den forste besigtigelse udbrod, at "den er lige til at rive ned og genopfore fra grunden". Det var imidlertid ikke mindst rektor Karl Mortensens fortjeneste, at den gamle hovedbygning fra 1854 fik lov til at blive stående. Foto: Institut for Sonderjysk Lokalhistorie.

med at finde plads til særlokaler til pigerne i mellemskolen, så som husgernings- og håndarbejdslokaler, samt til pigegymnastiksal. Det hjalp dog noget, at gymnasieklasserne i begyndelsen var små, men det varede længe, før lokaleforholdene i de sønderjyske gymnasieskoler var tilfredsstillende.

Såfremt der i statsskolerne blev pladsmangel som følge af den sideløbende danske og tyske skoleundervisning, skulle rektorerne sørge for, at skolebygningerne blev udnyttet hele eftermiddagen, således at der kunne oprettes både formiddags- og eftermiddagsklasser.

Rektorerne skulle sørge for indkøb af skolemateriel og brændsel og undersøge, om der ved skolen var en pedel, som kunne anses for egnet til ansættelse. Endvidere skulle det til ministeriet oplyses, hvor mange af skolens elever, der efter ferien ønskede at fortsætte på sko- 
len med tysk undervisningssprog og hvor mange, der ønskede at gå over til klasser med dansk undervisningssprog.

Ministeriet skulle også have svar på, om de ved skolen ansatte lærere efter overgangen til dansk administration var villige til uden forandring at fortsætte med undervisningen, indtil det danske lærerpersonale efter ferien kunne træde til. Sluttelig skulle ministeriet oplyses om, hvorvidt der blandt det daværende tyske lærerpersonale var lærere, der på de $\mathrm{i}$ instruksen angivne vilkår var villige til midlertidigt og i højst tre år at undervise $\mathrm{i}$ de højere tyske afviklingsklasser..$^{56}$

Rektorerne skulle forhandle med de kommunale myndigheder og med statsbanerne om køreplaner for udenbys elever, så tidspunkterne passede med skoletidens begyndelse og ophør, de ansatte lærere skulle indkaldes til lærermøder i juli måned, og forældremøder skulle afholdes. Dertil kom den daglige kontortid, hvor rektorerne skulle være til disposition, så forældre kunne møde op og få svar på spørgsmål vedrørende deres børns kommende skolegang, og endelig skulle rektorerne modtage indmeldelser og sørge for skemalægning og klassedannelser. ${ }^{57}$

I dagene 23.-26. august åbnede statsskolerne i Aabenraa, Tønder og Sønderborg. I Haderslev begyndte man først den 7. september pga. omfattende reparationsarbejde. Vi har mange beretninger om, hvor stort et indtryk disse åbningshøjtideligheder gjorde på deltagerne. Højdepunktet indtraf alle fire steder, da man sang Grundtvigs salme »Den signede dag med fryd vi ser«. En af deltagerne har beskrevet det således: "Det var den dag ikke kun en salme, og sidste vers var som en jubelsang: "Så rejse vi til vort fædreland, der ligger ej dag i dvale ... så frydelig der til evig tid med venner i lys vi tale.« Jeg har jo sunget den så mange gange, men den har aldrig tabt sin jubeltone for mig. ${ }^{58}$

\section{Skoleudvalget nedlægges}

I 1920 nedlagde man de udvalg, som Nordslesvigsk Vælgerforenings tilsynsråd havde oprettet i 1918, således også skoleudvalget.

Som tidligere nævnt havde skoleudvalgets medlemmer følt samarbejdet med ministeriet belastende. Man mente i udvalget, at de ministerielle embedsmænd ofte optrådte afvisende, og at der i ministeriet herskede en vis » $\mathrm{Vi}$ alene vide«-mentalitet. Jacob Appel fortæller, at 
der i eftersommeren 1919 havde været mange vanskeligheder og uvilje $i$ ministeriet og beretter videre om et møde $i$ ministeriet en af de første dage i november 1919. Her genså han en del af personalet fra sin tid som kultusminister 1910-1913, men nogle nye og for Appel ukendte embedsmænd var kommet til. Han skriver herom: "... ministeriets gamle personale var meget venlige imod mig og mine forslag. Desværre synes jeg ikke godt om et par af de nye embedsmænd. De er fyldt af mærkelige forestillinger om, at for at være retfærdige må de f.eks. påbyde tysk i alle danske folkeskoler. Det blev der nærmest leet af ... ${ }^{59}$

Der er ingen tvivl om, at der har været adskillige gode grunde til, at udvalgsmedlemmerne har følt samarbejdet med ministeriet besværligt. Spørgsmålet er imidlertid, hvor slemt det egentlig har været. Stridens æble var uafviseligt ordningen af skoleforholdene for det tyske mindretal og spørgsmålet om, hvor megen vægt der skulle lægges på faget dansk i de tyske skoler og på tysk i de danske skoler. Dertil kom så spørgsmålet om, i hvor høj grad statsmagten skulle have ret til at blande sig i lokale skolespørgsmål. I virkeligheden var man slet ikke så uenige endda, og der var fuld enighed om de overordnede mål. Man var dog gensidig usikker på modpartens motiver og bevæggrunde, og det var denne mistillid, der periodevis skabte problemer i samarbejdet.

Men, hvad der måske er mindre kendt, gik utilfredsheden med samarbejdet ikke kun fra udvalg til ministerium, men også den modsatte vej. Sidst i august 1919 følte undervisningsminister S. KeiserNielsen, at man gik bag ryggen på ham med hensyn til skoleforholdene i Sønderjylland. Det var årsagen til, at han sammen med H.P. Hanssen nedsatte et udvalg blandt andet med repræsentanter fra ministerium, undervisningsinspektion, seminarierne og lærerforeningerne, som skulle være rådgivende for skoleudvalget og for de nordslesvigske skolekommissioner vedrørende valget af lærere. ${ }^{60}$

Der er ingen tvivl om, at der både i skoleudvalg og i ministerium blev arbejdet ihærdigt på at få skabt så gode rammer som overhovedet muligt for de nye sønderjyske skoler, og ikke mindst på baggrund af den fantastisk store arbejdsindsats, som begge parter ydede, var det kedeligt, at samarbejdet ikke altid fungerede optimalt. 


\section{Afslutning}

Med åbningshøjtidelighederne i august/september 1920 var to års forberedelse af det højere skolevæsen i Sønderjylland slut. Både centralt og lokalt havde forberedelsesarbejdet taget sit udspring i ønsket om forsoning mellem dansk og tysk i grænselandet. Det havde været det overordnede mål. De nye sønderjyske gymnasieskoler skulle bygge på fredelig sameksistens og på respekt for andres synspunkter på tværs af sprog og grænse og ud fra ønsket om, at menneskelige idealer måtte sejre. Det var den eneste farbare vej fremad. $\mathrm{Og}$ i den ånd begyndte de nye gymnasieskoler arbejdet.

FORKORTELSER

$\begin{array}{ll}\text { Ap } & \text { Jacob Appels privatarkiv. } \\ \text { Dept } & \text { 05050A. RA } \\ \text { DsM } & \text { Departement } \\ & \text { Det sønderjyske } \\ \text { Jo } & \text { Ministerium } \\ \text { Kt } & \text { Journalnummer } \\ \text { LAA } & \text { Kontor } \\ \text { Pk } & \text { Landsarkivet i Aabenraa } \\ \text { RA } & \text { Pakke } \\ \text { Sst } & \text { Rigsarkivet } \\ \text { Sa } & \text { Sammesteds } \\ \text { Underv.min. } & \text { Sønderjyske Årbøger } \\ \text { Undervisningsministeriet }\end{array}$

\section{NOTER}

1. Wilhelm von Rosen (red.): »Rigsarkivet og hjælpemidleme til dets benyttelse. « II, 4 s.1888. 1991.

2. Brev af 12. april 1919 fra Jefsen Christensen til Jacob Appel. Ap pk 5.

3. Brev af 15. april 1920 fra Jefsen Christensen til Jacob Appel. Ap pk 5.

4. Nicolai Svendsen: "Sønderjydsk skæbne III. I Genforeningens tjeneste s. 19. Historisk Samfund for Sønderjylland. 1968 + Chr.P. Hansen: "Jacob Appel - Sonderjydernes trofaste talsmand «. Flensborg Avis 11. december 1956+Margrethe Christiansen: "Jacob
Appel - en mand og hans arv« s. $256 \mathrm{f}$. Kristeligt Dagblads Forlag. 1970.

5. Forhandlingsprotokol for Det nordslesvigske Skoleudvalg. Møde 28. januar 1919. LAA.

6. Underv.min. 2. dept 1. kt Jo 2399/ 1919.

7. Underv.min. 2. dept 1. kt Jo 1284/ 1919 + DsM Jo 173.3.19.

8. Årsskrift 1999 for Historisk Forening for Gråsten By og Egn s. 5-7.

9. Forhandlingsprotokol for Det nordslesvigske Skoleudvalg. Møder 7. og 30. april 1919. LAA.

10. Underv.min. 2. dept 1. kt Jo 1284/ 1919.

11. DsM Jo 173.3.1919.

12. Underv.min. 2. dept 1. kt Jo 1284/ 1919 + Forhandlingsprotokol for Det nordslesvigske Skoleudvalg. Møde 11. oktober 1919. LAA.

13. Se f.eks. Underv.min. 2. dept 1 . kt Jo 1632/1919.

14. Nicolai Svendsen: "I Genforeningens tjeneste« s. 59. Historisk Samfund for Sonderjylland. 1968.

15. Kaj Sørensen: "Rektor A. Egeberg Jensen - en sønderjysk skolemand «. Så 2001 s. 237.

16. Underv.min. 2. dept 1. kt Jo 601/1919.

17. Sst.

18. Levnedsberetninger fra A.J. West og I.M. Hertz i Ordenskapitlet på 
Amalienborg. $+\mathrm{I}$. Mogensen: Aabenraa Statsskole 1920-1945 s. 9. Desuden ligger der i journalsag 277/1920 i Undervisningsministeriet 2. dept 1. kt et lille håndskrevet stykke papir, som har cirkuleret mellem ministeriets øverste embedsmænd vedrørende besættelsen af et rektorat i Flensborg, såfremt denne by kom under dansk styre, og af dette papir fremgår det ligeledes, at besættelsen af rektorstillingerne foregik ved direkte henvendelse til de personer, ministeriet onskede ansat.

19. Underv.min. 2. dept 1. kt Jo $1719 /$ 1920.

20. J.M. Hertz: Levnedsberetning s. 1-4. Ordenskapitlet. Amalienborg.

21. Forestillinger. Kongelige resolutioner vedrørende Underv.min. 2. dept for året 1920. RA.

22. Sst.

23. J.M. Hertz: Levnedsberetning s. 5 . Ordenskapitlet. Amalienborg.

24. Underv.min. 2. dept 1. kt Jo 587/1918.

25. Sst.

26. Georg Buchreitz: »Tale ved 50 års jubilæet« i Aabenraa Statsskole 19201970 s. 38f. Aabenraa 1971.

27. Undervisningsinspektionen for gymnasieskolerne. Inspektioner 19061916. RA.

28. Underv.min. 2. dept 1. kt Jo 433/1918.

29. Sst.

30. Undervisningsinspektionen for gymnasieskolerne. Inspektioner 19061916. RA.

31. Margrete Schultz: "Erindringer fra Tønder 1904-1923«. Så 1987 s. 159.

32. Underv.min. 2. dept. 1. kt. Jo 379/ 1930.

33. Ernst A. Kiørboe: „Et par spredte træk til en skitse af rektor West « i Tonder Statsskole 1920-1945 s. 64 . Tonder 1945.

34. Sst+A.J. West: Levnedsberetning s. 3. Ordenskapitlet. Amalienborg + Sonderborg Statsskole 1920-1945 s. 50. Sonderborg 1945.

35. Underv.min. 2. dept 1. kt Jo 1719/ 1920. + Undervisningsinspektionen for gymnasieskolerne. Kopibog 19181920. Brev nr. 280.

36. Underv.min. 2. dept 1. kt Jo 250/1920.

37. Nicolai Svendsen: "I Genforeningens tjeneste« s. 42. Historisk Samfund for Sonderjylland. 1968 + Franz v. Jessen: "Håndbog $\mathrm{i}$ det slesvigske spørgsmåls historie 1900-1937 « bd. III s. 154. Udgivet af Grænseforeningen. Kobenhavn 1938 + A.J. West: "Tønder Statsskole 1920-1935« s. 4. Tønder. 1935.

38. Forhandlinger i Rigsdagspartiernes sønderjydske Udvalg 1919-1920 s. $1023+1026$.

39. Underv.min. 2. dept 1. kt Jo 1284/ 1919.

40. Forhandlinger i Rigsdagspartiernes sønderjydske Udvalg 1919-1920 s. 352.

41. Undervisningsinspektionen for gymnasieskolerne. Kopibog 1918-20. Brev nr. 270.

42. Forhandlinger i Rigsdagspartiernes sonderjydske Udvalg 1919-1920 s. 1022.

43. Statstidende 4. marts 1920.

44. Statstidende 15. maj 1920.

45. Underv.min. Gruppeordnede sager 1916-1968. Ansøgningsprotokol for embeder under Undervisningsministeriet 1913-1922.

46. Underv.min. 2. dept 1 . kt journaler med registre 1918-1920.

47. Underv.min. 2. dept 1. kt Jo 271/1920.

48. Sst. + Underv.min. 2. dept 1. kt Jo 564/1920.

49. Underv.min. 2. dept 1. kt Jo 271/1920.

50. Brev af 2 . juni 1920 fra undervisningsinspektor Henrik Bertelsen. Underv.min. 2.dept 1. kt Jo 564/1920.

51. Sst.

52. Med den bemærkning hentydes der til, at der blandt de kvalificerede ansøgere kun lige netop var det nodvendige antal matematiklærere, og da en af disse lærere kun søgte en stilling i Sonderjylland, såfremt han samtidig blev udnævnt til lektor, så ministeriet sig altså nødsaget til at foretage yderligere en lektorudnævnelse, hvilket fik kontorchefen til at sukke: "Matematikere kan jo stille deres betingelser! «

53. Underv.min. 2. dept 1. kt Jo 564/1920.

54. Underv.min. 2. dept 1. kt Jo 562/1920.

55. Sst.

56. Underv.min. 2. dept 1. kt Jo 1719/ 1920. 
57. Undervisningsinspektionen for gymnasieskolerne. Kopibog 19181920. Brev nu. 280.

58. Margrete Schultz: "Erindringer fra Tønder 1904-1923《. Så 1987 s. 157.

59. Margrethe Christiansen: "Jacob Ap- pel - En mand og hans arv" s. 288f. Kristeligt Dagblads Forlag. 1970.

60. Sst + Forhandlingsprotokol for Det nordslesvigske Skoleudvalg. Møder 22/8-1919 og 4/9-1919. LAA. 